\title{
1 Long-term (1990-2019) monitoring of tropical moist forests dynamics
}

2 C. Vancutsem ${ }^{1 *}$, F. Achard ${ }^{1}$, J.-F. Pekel ${ }^{1}$, G. Vieilledent ${ }^{1,2}$, S. Carboni $^{3}$, D. Simonetti ${ }^{1}$, J. Gallego ${ }^{1}$, $3 \quad$ L. $\mathrm{Aragao}^{4}, \mathrm{R} \cdot \mathrm{Nasi}^{5}$

$4{ }^{1}$ European Commission, Joint Research Centre, Via E. Fermi 2749 - TP 261, I-21027 Ispra (VA), 5 Italy.

$6 \quad{ }^{2}$ CIRAD, UPR Forêts et Sociétés, F-34398 Montpellier, France.

$7 \quad{ }^{3}$ GFT Italia Srl, Milan, Via Sile 18, Italy.

$8 \quad{ }^{4}$ National Institute for Space Research (INPE), São José dos Campos, Brazil.

$9 \quad{ }^{5}$ Center for International Forestry Research (CIFOR), Bogor, Indonesia.

$10 *$ Correspondence to: $\underline{\text { Christelle.vancutsem@gmail.com }}$

12 ABSTRACT

13 Accurate characterization of the tropical moist forests changes is needed to support conservation 14 policies and to better quantify their contribution to global carbon fluxes. We document - at 15 pantropical scale - the extent of these forests and their changes (degradation, deforestation and 16 recovery) over the last three decades. We estimate that $17 \%$ of the tropical moist forests have 17 disappeared since 1990 with a remaining area of 1060 million ha in 2019 , from which $8.5 \%$ are degraded. Our study underlines the importance of the degradation process in such ecosystems, in 19 particular as precursor of deforestation and in the recent increase of the tropical moist forest 20 disturbances. Without reduction of the present disturbance rates, undisturbed forests will disappear 21 entirely in large tropical humid regions by 2050. Our study suggests reinforcing actions to prevent 22 the first disturbance scar that leads to forest clearance in $45 \%$ of the cases. 


\section{INTRODUCTION}

25 Tropical moist forests (TMF) have a huge environmental value. They play an important role in 26 biodiversity conservation, terrestrial carbon cycle, hydrological regimes, indigenous population 27 subsistence and human health (1-5). They are increasingly recognized as an essential element of any strategy to mitigate climate change $(6,7)$. Deforestation, and degradation compromise the functioning of tropical forests as an ecosystem, lead to biodiversity loss $(\mathbf{1}, \mathbf{4 , 5 , 8 , 9 )}$ and reduced carbon storage capacity (10-17). Deforestation and fragmentation are increasing the risk of virus disease outbreaks (18-20).

For humanity wellbeing, sustainable economic growth and conservation of the remaining TMF constitute one of the largest challenges and shared responsibility. A consistent, accurate and geographically explicit characterization of the long-term disturbances at the pantropical scale is a prerequisite for elaborating a coherent territorial planning towards Sustainable Development Goals (SDGs) and the Nationally determined contributions (NDCs) of the Paris Agreement (2015). Advances in remote-sensing, cloud computing facilities, and free access to the Landsat satellite archive (21-23), enable systematic monitoring and consistent dynamic characterization of the entire TMF across a long period. Global maps have been derived to quantify tree cover loss since 2000 information on the long-term dynamics of tropical moist forests and particularly on forest degradation and post-disturbances development stages is still missing to accurately estimate the carbon loss associated with forest disturbances $(2, \mathbf{1 3}, \mathbf{1 5})$ and assess their impact on biodiversity $(5,8)$. 
49 RESULTS AND DISCUSSION

50 Here we provide new information through a wall-to-wall mapping of tropical moist forest cover 51 dynamics over a long-term period (January 1990 to December 2019) at 0.09 ha resolution (freely available from https://forobs.jrc.ec.europa.eu/TMF/) (see Materials and Methods). This validated dataset depicts the TMF extent and the related disturbances (deforestation and degradation), and post-disturbances recovery on an annual basis over the last three decades (see Supplementary Text on the annual change dataset, and fig. S1). A major innovation consists of characterizing the sequential dynamics of changes by providing transition stages from the initial observation period to the end of the year 2019, i.e. undisturbed forest, degraded forest, forest regrowth, deforested land, conversion to plantations, conversion to water, afforestation, and changes within the mangroves (Figs. 1 and 2, see Supplementary Text on the transition map and figs. S2 to S7), as well as the timing (dates and duration), recurrence and intensity of each disturbance.

For the first time at the pantropical scale the occurrence and extent of the forest cover degradation is documented on an annual basis in addition to the deforestation. This has been achieved thanks to the analysis of each individual valid observation of the Landsat archive (see Data and Mapping method Sections) allowing to capture short-duration disturbances such as selective logging (Fig. 2F, fig. S3), fires (Fig. 2B), and severe weather events (hurricanes, dryness) (fig. S7). quantified based on a sample-based reference in accordance with the latest statistical good practices (26) and indicates an underestimation of the forest disturbance areas by $11.8 \%$ (representing 38.4 million ha, with 15 million ha confidence interval at 95\%) (see Section and Supplementary Text on the validation, figs. S8 to S10 and tables S1 to S4). 


\section{Main results on degradation}

The analysis of the yearly dynamics of TMF disturbances over the last 30 years underlines the importance of the degradation process in tropical moist forest ecosystems with the following key outcomes (Tables 1, 2 and 3, the Trend analysis section in Materials and Methods, fig. S11):

(i) During the last three decades, 195.1 million ha of TMF have disappeared and 106.5 million ha are in a degraded status (Table 3). This represents $8.4 \%$ of the 1059.6 million ha of forest area remaining in January 2020. Degraded forests represent 33\% of the observed disturbances with high variability between regions and countries, ranging from $96 \%$ in Venezuela, $74 \%$ in Gabon, and 69\% in Papua New Guinea to $21 \%$ in Brazil and Madagascar, and 13\% in Cambodia (Table S6). $40.7 \%$ of the degraded forests are in Asia-Oceania (compared to 36.9\% in Latin America and 22.3\% in Africa) (Table 3).

(ii) $84.5 \%$ of the degraded forests (i.e. 90 million ha) are resulting from short-term disturbances (observed over less than 1-year duration, mostly due to selective logging, natural events and light-impact fires), from which 30 million ha have been degraded repeatedly 2 or 3 times over the last 30 years (observed each time along a short-term period). The remaining $15.5 \%$ (16.5 million ha) are mainly resulting from intense fires, with a disturbance duration between 1 to 2.5 years.

(iii) $45.4 \%$ of the degradation ( 88.6 million ha) is a precursor of deforestation events occurring on average after 7.5 years (without significant variability between continents). This is particularly true for South-East Africa and South-East Asia that show respectively $60.4 \%$ (with $65 \%$ for Madagascar) and 53\% (with 59\% for Cambodia) of degraded forests becoming deforested in a second step (Table 2). These proportions are underestimated because $45.4 \%$ of recent degradation (e.g. in the last 7 years) will most likely be deforested in future years. 
(iv) A further $30.3 \%$ of the undisturbed forest areas (291.8 million ha) are potentially disturbance-edge-affected forests, i.e. located within 120 meters from a disturbance (see Materials and Methods). This proportion indicates a higher forest fragmentation proportion in Asia (45.2\%) compared to other continents (25.6\% and 28.9\% respectively in the Americas and Africa).

(v) $82.8 \%$ of the TMF mapped as degraded in December 2019 corresponds to short-term disturbances that have never been identified so far at the pan-tropical scale. Over the period covered by the Global Forest Change (GFC) product (24), i.e. 2001-2019, 21.2 million ha have been captured as a tree cover loss compared to 86 million ha detected as degraded forests by our study during the same period (see Section on the comparison with the GFC dataset, Fig. 4 and table S5).

(vi) We show that the annual rate of degradation is highly related to climatic conditions (Figs. 3 and 4, fig. S11). Whereas the trends in deforestation rates seem to be related to changes in national territorial policies, degradation rates usually show peaks during drought periods and do not seem to be impacted by forest conservation policies. The drought conditions that occurred during strong and very strong El Niño southern oscillation (ENSO) events of 1997-1998 and 2015-2016 were optimal for forest fires (27-29) and resulted in a strong increase of forest degradation (28). The impact of these fires in 2015-2016 is particularly strong and visible in all regions except in South-East Africa.

Our results stress the paramount importance of (i) integrating measures for reducing degradation in forest conservation and climate mitigation programs, and (ii) considering forest degradation as risk factor of deforestation and as an indicator of climate change and climate oscillations. We anticipate that a better knowledge of forest degradation processes and its resulting fragmentation will help to 
assess accurately the anthropogenic impact on the tropical ecosystem services and the effects on biosphere-atmosphere-hydrosphere feedbacks. Future policies will have to account for this finding.

\section{Main results on deforestation and post-deforestation regrowths}

Deforestation in TMF cover is documented in an unprecedented comprehensive manner: (i) by covering a 30-year period of analysis, (ii) by mapping deforestation occurring after degradation and deforestation followed by a regrowth, (iii) by identifying specific forest conversion to commodities or water (Figs. 2G and 2I), (iv) by including changes within the mangroves (Fig. 2A), and (v) by documenting each deforestation event at the pixel level by its timing (date and duration), intensity, recurrence and when appropriate, start date and duration of post-disturbance regrowth.

Overall, $17.2 \%$ of the initial TMF area (i.e. 207.4 over 1267.1 million ha), have disappeared since 1990, down to 1059.6 million ha of TMF in January 2020 (Tables 1, 2 and 3). We report a rate of gross loss of TMF area for the entire pan-tropical region varying from 5.5 to 7.7 million ha / year with the period (Table 4). Comparison with previous studies results in the following outcomes:

(i) Estimations reported by FAO national statistics (30) and the sample-based estimations from Tyukavina et al. (31) for the natural tropical forest - that includes both moist and dry forest types - are higher by $0.9 \%$ and $27 \%$ respectively, compared to our TMF deforestation rates (excluding the conversion to tree plantations to get closer to the natural forest definition of these two studies) for the same period (Table 4). At the continental scale, Tyukavina et al. (31) shows lower estimates than our study for Africa (-23\%) and for Asia (-4\%), and higher estimates for Latin America (+16\%).

(ii) Comparison with GFC loss (24) (see Section on the Comparison with the GFC dataset and Fig. 4) shows a lower deforestation rate (-33\%) compared to our study for the period 2000- 
2012 over the same forest extent (using our TMF extent for the year 2000) (Table 4). Underestimation of GFC loss has been documented by previous studies $(\mathbf{3 1}, \mathbf{3 3})$. Tyukavina et al. (31) reported an underestimation of GFC loss of 19.4\% considering the entire forest cover (moist and deciduous) loss during the period 2001-2012, with a larger underestimation for Africa (-39.4\%) compared to other continents (-13\% for Latin America and $-5.7 \%$ for Asia). The ranking of this underestimation by continent is consistent with the ranking observed in our study (first Africa, second Latin America and third Asia). The differences with GFC loss are explained by three specific assets of our approach: (i) the use of single-date images enabling the detection of short-duration disturbance events (i.e. visible only during a few weeks from space) compared to the use of annual syntheses, (ii) a dedicated algorithm for TMF enabling the monitoring of seven forest cover change classes compared to the global monitoring of forest clearance, and (iii) a cloud masking and quality control optimized for equatorial regions enabling a more comprehensive analysis of the Landsat archive.

(iii)Comparison with the Brazilian PRODES data (29) using their primary forest extent (Fig. 4) shows a similar decrease of annual deforestation rates between the 2000's and the last decade that can be related to a set of economic and public policy actions (28). Differences in the deforestation rates are observed (i) during the period 2001-2004 with a higher deforestation rate for PRODES (2.32 million ha/year) compared to our study ( 2 million ha/year) and to GFC loss (1.53 million ha/year), and (ii) in the last ten years with a lower average deforestation rate for PRODES compared to our study and GFC loss $(0.67,1.1$ and 1.34 million ha/year respectively) (Table 4). These differences are accentuated in the last five years $(0.77,1.33$, and 1.76 million ha/year respectively). Discrepancies in area estimates between our product and the PRODES data are explained by (i) difference in minimum mapping units (0.09 ha compared to 6.25 ha in PRODES), and (ii) impacts of 
strong fires that are captured in our study (deforestation followed by forest regrowth) and in GFC loss but are discarded in the PRODES approach (because not considered as deforestation).

This study documents - in an unprecedented manner - the extent and age of post-deforestation regrowths (young secondary forests that are regenerating after human or natural disturbance) for the entire pan-tropical domain. These secondary forests grow rapidly in tropical moist conditions and absorb large amounts of carbon, whereas they were poorly documented. We show that $13.5 \%$ of the deforested areas (i.e. 29.5 Million ha) are regrowthing in a subsequent stage, with $33 \%$ of these secondary forests aged more than 10 years at the end of 2019 (Table 3). The proportion of secondary forests within the total deforestation is higher in Asia $(18.3 \%)$ compared to Latin America (12.3\%) and Africa (7.9\%). The disturbance events followed by a forest regrowth are including intense fires and these are accentuated by drought conditions. This is well visible for South America (Fig. 3) for years 1997-1998 and 2010. Additionally, 10 Million ha are characterized as evergreen vegetation regrowth of areas initially classified as non-forest cover, i.e. that can be considered as forestation (i.e. afforestation and reforestation) aged of more than 10 years.

This study confirms that most of the deforestation caused by the expansion of oil palm and rubber and assigned to the commodity classes in our study (see Supplementary Text on ancillary datasets, Figs. 2I and 3B, Fig. S11 and table S6) is concentrated in Asia with 18.3 million ha (representing $86 \%$ of the entire TMF conversion to plantations), and more specifically in Indonesia (57.4\%) and Malaysia (23.8\%). 


\section{Deforestation and degradation trends}

The evolution of the deforestation and degradation over the last three decades show the highest peaks of annual disturbances in Latin America and Southeast Asia during the period 1995-2000 with 6.3 million ha/year and 6.2 million ha/year respectively. The ENSO of 1997-1998 may - at least partially - explain these peaks of forest disturbances, in particular for Indonesia and Brazil where such peaks are manifest in the annual change trends with the highest proportion of degradation events over the total disturbance areas (Figs. 3 and 5, fig. S11). Between 2000-2004 and 2015-2019, the disturbance rates decreased by half in South-America and by $45 \%$ in SouthEast Africa and continental South-Est Asia. Brazil - that accounts for $29 \%$ of the remaining world's TMF - largely contributed to this reduction (from 4.3 million ha/year down to 2.1 million ha/year) (Figs. 3, 4, and 5, Table 4, table S6 and fig. S11).

In the recent years, our study shows a dramatic increase of disturbances rates (deforestation and degradation) $(+2.1$ million ha/year for the last 5 years compared to the period 2005-2014) to reach a level close to that of the early 2000s (Tables $\mathbf{2}$ and 3) with the highest increases observed in West Africa and Latin America (48\% higher). Degradation is the main contributor of this recent increase (average increase of $38 \%$ whereas annual deforestation decreased by $5 \%$ ) caused notably by specific climatic conditions in 2015-2016 (29) (Figs. 3 and 5). Asia-Oceania region shows a lower increase of degradation rate (31\%) compared to Africa (34\%) and Latin America (49\%) and a much higher decrease of deforestation rate (28\%) compared to Africa (5\%) and Latin America (12\%). 


\section{Undisturbed TMF decline and projections}

219 Since 1990, the extent of undisturbed TMF has declined by $23.9 \%$ with an average rate of loss of 22010.8 million ha/year. The decline of undisturbed TMF is particularly dramatic for Ivory Coast 221 (81.5\% of their extent in 1990), Mexico (73.7\%), Ghana (70.8\%), Madagascar (69\%), Vietnam

(67.8\%), Angola (67.1\%), Nicaragua (65.8\%), Lao People's Democratic Republic (PDR) (65.1\%), and India (63.9\%) (table S6). If the average rates of the period 2010-2019 would remain constant over a short or medium term future (see Materials and Methods, fig. S12), undisturbed TMF would disappear by 2026-2029 in Ivory Coast and Ghana, by 2040 in Central America and Cambodia, by 2050 in Nigeria, Lao PDR, Madagascar and Angola, and by 2065 for all the countries of continental Southeast Asia and Malaysia. By 2050, 15 countries -including Malaysia (the $9^{\text {th }}$ country with the biggest TMF forest) - will lose more than 50\% of their undisturbed forests (table S6).

\section{CONCLUSION}

It is now possible to monitor deforestation and degradation in tropical moist forests consistently over a long historical period and at fine spatial resolution. The mapping of forest transition stages will allow to derive more targeted indicators to measure the achievements in forest, biodiversity, health and climate policy goals from local to international levels (34). Our study shows that tropical moist forests are disappearing at much faster rates than what was previously estimated and underlines the precursor role of forest degradation in this process. These results should alert decision makers on the pressing need to reinforce actions for preserving tropical forest, in particular by avoiding the first scar of degradation that is most likely leading to forest clearance later on. 


\section{MATERIALS AND METHODS}

$243 \quad$ Study area and Forest types

244 Our study covers the tropical moist forests, which include the following formations (35): the 245 lowland evergreen rain forest, the montane rain forest, the mangrove forest, the swamp forest, the 246 tropical semi-evergreen rain forest, and the moist deciduous forest. Evergreenness varies from 247 permanently evergreen to evergreen seasonal (mostly evergreen but with individual trees that may 248 lose their leaves), semi-evergreen seasonal (up to about one third of the top canopy can be 249 deciduous, though not necessarily leafless at the same time), and moist deciduous (dominant 250 deciduous species with evergreen secondary canopy layer).

We do not intent to map specifically intact or primary forest as the Landsat observation period is too short to discriminate never-cut primary forest from second growth naturally recovered forest older than the observation period. However, by documenting all the disturbances observed over the last three decades, the remaining undisturbed TMF in 2019 is getting closer to the primary forest extent. Whereas our entire TMF - that includes undisturbed and degraded forests - in 1990 and 2019 are comparable, our undisturbed forest of 1990 and 2019 should be carefully compared.

Our study area covers the following Global Ecological Zones (36): 'Tropical rainforest', 'Tropical moist forest', 'Tropical mountain system' and 'Tropical dry forest' (fig. S13) and stops at the borders of China, Pakistan, Uruguay, and USA. The TMF are located mostly in the tropical moist and humid climatic domains but also include small areas of gallery forests in the tropical dry domain. 


\section{Data}

268 The Landsat archive is the only free and long-term satellite image record suited for analysing vegetation dynamics at fine spatial resolution. We used the entire L1T archive (orthorectified top of atmosphere reflectance) acquired between July 1982 and December 2019 from the following Landsat sensors: Thematic Mapper (TM) onboard Landsat 4 and 5, Enhanced Thematic Mapperplus (ETM+) onboard Landsat 7 and the Operational Land Imager (OLI) onboard Landsat 8 (23, 37-39). Landsat 4 was launched in July 1982 and collected images from its TM sensor until

December 1993. Landsat 5 was launched in March 1984 and collected images until November 2011. Landsat 7 was launched in April 1999 and acquired images normally until May 2003 when the scan line corrector (SLC) failed (40). All Landsat 7 data acquired after the date of the SLC failure have been used in our analysis. Landsat 8 began operational imaging in April 2013.

The Landsat archive coverage presents large geographical and temporal unevenness $(\mathbf{3 7}, \mathbf{4 1})$. The main reason for the limited availability of images for some regions is that Landsat 4 and 5 had no onboard data recorders, and links with data relay satellites failed over time; cover was therefore often limited to the line of sight of receiving stations (39). Commercial management of the programme from 1985 to the early 1990s led to data acquisitions being acquired mostly when preordered (37). From 1999 onwards, the launch of Landsat 7 and its onboard data recording capabilities, associated with the continuation of the Landsat 5 acquisitions, considerably improved global coverage.

In the tropical regions, Africa is particularly affected by the limited availability of image acquisitions, especially in the first part of the archive. From a total of around 1370860 Landsat scenes that were available for our study area, only 265098 scenes were located in Africa (in comparison, 573589 and 532173 scenes were respectively available in South America and Asia). 
292 The most critical area is located around the Gulf of Guinea, with an overall average number of valid 293 observations (i.e. without clouds, hazes, sensor artefacts and geo-location issues) over the full archive (fig. S14) of fewer than 50 per location (pixel) and with the first valid observations starting mostly at the end of the 1990s (fig. S15). Small parts of Ecuador, Colombia, Salomon Islands and Papua New Guinea present a similar low number of total valid observations, often with an earlier Africa and Southeast Asia, respectively.

first valid observation around the end of the 1980s. Apart from these regions, the first valid observation occurs mostly within periods 1982-1984, 1984-1986, or 1986-1988 for Latin America,

The average number of annual valid observations (fig. S16) shows a stepped increase during the 38-year period for the three continents, with two major jumps: in 1999 with the launch of Landsat 7, and in 2013 with the launch of Landsat 8. There is also a clear drop in 2012 for Southeast Asia and Latin America with the decommissioning of Landsat 5 in November 2011, and a small drop in 2003 as a consequence of the Landsat 7 SLC off issue. There are major differences between Africa and the two other continents: Africa has significantly fewer valid observations, in particular during the period 1982-1999, and a much larger increase in number of observations from 2013.

The geographical unevenness of the first year of acquisition constrains the monitoring capability period. Our method accounts for this constraint notably by recording the effective duration of the archive at the pixel level (see next subsection).

Data quality issues affecting the Landsat collection were addressed by excluding pixels where (i) detector artefacts occur (manifested as random speckle or striping), (ii) one or more spectral bands are missing (typically occurring at image edges) or (iii) scene geo-location is inaccurate. 


\section{Mapping method}

In order to map the area dynamics (extent and changes) of the TMF over a long period, we developed an expert system that exploits the multispectral and multitemporal attributes of the Landsat archive to identify the main change trajectories over the last 3 decades and uses ancillary information to identify sub-classes of forest conversion (see Supplementary Text on Ancillary data). The inference engine of our system is a procedural sequential decision tree, where the expert knowledge is represented in the form of rules. Techniques for big data exploration and information extraction, namely visual analytics (42) and evidential reasoning (43), were used similarly to a recent study dedicated to global surface water mapping (41). The advantages of these techniques for remotely sensed data analysis are presented in this previous study (41), notably for accounting for uncertainty in data, guiding and informing the expert's decisions, and incorporating image interpretation expertise and multiple data sources. The expert system was developed and operated in the Google Earth Engine (GEE) geospatial cloud computing platform (22).

The mapping method includes four main steps described hereafter: (i) single-date multi-spectral classification into three classes, (ii) analysis of trajectory of changes using the temporal information and production of a 'transition' map (with seven classes) (Figs. 1 and 2, figs. S2 to S7), (iii) identification of sub-classes of transition based on ancillary datasets (see Supplementary Text on Ancillary datasets) and visual interpretation, (iv) production of annual change maps (fig. S1).

In the first step, each image of the Landsat archive was analysed on a single-date basis (through a multi-spectral classification), whereas previous large-scale studies used annual syntheses or intraannual statistics such as the mean and standard deviation of available Landsat observations (44-50). Classification of individual images is challenging but presents three main advantages: it allows (i) to capture the disturbance events that are visible only over a short period from space, such as 
logging activities, (ii) to record the precise timing of the disturbances and the number of disruption observations, and (iii) to detect the disturbance at an early stage, i.e. even if the disturbance is starting at the end of the year, it is detected and counted as a disturbance for this year whereas other approaches notably based on composites will detect the disturbance with a delay of one year.

A disruption observation is defined here as an absence of tree foliage cover within a 0.09 ha size Landsat pixel. The number of disruption observations constitutes a proxy of disturbance intensity. Each pixel within a Landsat image was initially assigned through single-date multi-spectral classification to one of three following classes: (i) potential moist forest cover, (ii) potential disruption, and (iii) invalid observation (cloud, cloud shadow, haze and sensor issue).

The temporal sequence of classes (i) and (ii) was then used to determine the seven transition classes, described in the second step of the mapping approach. However, not all pixels could be unambiguously spectrally assigned to one of the three single-date classes because the multi-spectral cluster hulls of such classes are overlapping in the multidimensional feature-space. In cases of spectral confusion, evidential reasoning was used to guide class assignment by taking into consideration the temporal trajectory of single-date classifications, as spectral overlap between land cover types may occur only at specific periods of the year. For instance, pixels covered by deciduous forests, grassland or agriculture, may behave - from a spectral point of view - as potential moist forest cover during the humid seasons and as potential disruptions during the dry seasons, and, consequently, can be assigned to the other land cover transition class. Disturbed moist forests (degraded or deforested) are appearing as potential moist forest cover at the start of the archive and as potential disruption assignments later.

For the three initial classes (potential moist forest cover, potential disruption, and invalid observation), multispectral clusters were defined first by establishing a spectral library capturing 
the spectral signatures of the land cover types and atmosphere perturbations that are present over the pan-tropical belt and targeted for these three classes : (i) moist forest types, (ii) deciduous forest, logged areas, savannah, bare soil, irrigated and non-irrigated cropland, evergreen shrubland and water (for the potential disruption class) and (iii) clouds, haze, cloud shadows (for the invalid observations). A total sample of 38326 sampled pixels belonging to 1512 Landsat scenes (L5, L7 and L8), were labelled through visual interpretation. The HSV (hue, saturation, value) transformation of the spectral bands - well adapted for satellite image analysis $(\mathbf{4 1}, \mathbf{5 2})$ - were used to complement the spectral library. These components were computed using a standard transformation (52) for the following Landsat band combination: short-wave infrared (SWIR2), near infrared (NIR) and red. The stability of hue to the impacts of atmospheric effect is particularly desirable for identifying potential disruption in the humid tropics. The sensitivity of saturation and value to atmospheric variability is mainly used to detect invalid observations (haze). Value is particularly useful for identifying cloud shadows. The thermal infrared band (TIR) was relevant to detect invalid observations (clouds, haze) and bare soil, and the Normalized Difference Water Index (NDWI) to identify irrigated areas. The information held in the spectral library was analyzed through visual analytics to extract equations describing class cluster hulls in the multidimensional feature-space (fig. S17). An exploratory data analysis tool designed in a previous study (41) was used to support the interactive analysis.

In the second step of the mapping approach, the temporal sequence of single-date classifications at pixel scale was analysed to first determine the initial extent of the TMF domain and then to identify the change trajectories from this initial forest extent (fig. S2). Long-term changes cannot be determined uniformly for the entire pan-tropical region because the observation record varies (see Data), e.g. the first year of observation (fig. S18) is c. 1982 for Brazil and c. 2000 along the Gulf of Guinea. We have addressed this geographic and temporal discontinuities of the Landsat 
archive by determining at the pixel level (i) a reference initial period (baseline) for mapping the initial TMF extent and (ii) a monitoring period for detecting the changes. The data gaps at the beginning of the archive were tackled by requiring a minimum period of four years with a minimum of three valid observations per year or a minimum of five years with two valid observations per year from the first available valid observation. Hence, lower is the annual number of valid observations, higher is the length of the initial period. This minimizes the risk of inclusion of nonforest cover types (such as agriculture) and deciduous forests in the baseline when there are few valid observations over a short period. In addition, we have reduced the commission errors in our baseline by accounting for possible confounding with commodities, wetlands, bamboo, and deciduous forest (see Supplementary Text on ancillary datasets and specific tropical forest types). From our initial TMF extent, we identified seven main transition classes (fig. S2) which are defined thereafter. The first year of the monitoring period (that follows the initial period) is represented at fig. S18; it starts at the earliest in year 1987 (mostly for South-America) and, for very limited cases, at the latest in 2016 (e.g. Gabon).

Although no ecosystem may be considered truly undisturbed, because some degree of human impact is present everywhere (54), we define the undisturbed moist forests (class 1) as tropical moist (evergreen or semi-evergreen) forest coverage without any disturbance (degradation or deforestation) observed over the Landsat historical record (see Section on the Study area and forest types). Our TMF baseline may include old forest regrowth (old secondary forests) or previously degraded forests forest as the Landsat observation period is too short to discriminate never-cut primary forest from second growth naturally recovered forest older than the observation period. This class includes two sub-classes of bamboo-dominated forest (class 1a) and undisturbed mangrove (class 1b). 
416 A deforested land (class 2) is defined as a permanent conversion from moist forest cover to another

417 land cover whereas a degraded forest (class 3 ) is defined as a moist forest cover where disturbances were observed over a short time period. Here we assumed that the duration of the disturbance (and consequently the period over which we detect the disturbance with satellite imagery) is a proxy of

on the forest, and higher is the risk to have a permanent conversion of the TMF. By considering short-term disturbances we include logging activities, fires and natural damaging events such as wind breaks and extreme dryness periods. Hence, we are getting closer to the most commonly accepted definition of the degradation (54) that considers a loss of productivity, a loss of biodiversity, unusual disturbances (droughts, blowdown), and a reduction of carbon storage.

The threshold applied on the duration parameter used to separate degraded forests from deforested land is based on our knowledge of the impacts of human activities and of natural or human-induced events such as fires. We identified empirically two levels of degradation: (class 3a) degradation with short-duration impacts (observed within a 1-year maximum duration), which includes the majority of logging activities, natural events and light fires, and (class 3b) degradation with longduration impacts (between one and 2.5 years) which mainly corresponds to strong fires (burned forests). Most of the degradation (50\%) are observed over less than six-month durations (fig. S19). All disturbance events for which the impacts were observed over more than 2.5 years (900 days) were considered as deforestation processes, with $68 \%$ of such deforestation events observed over more than five years. When a deforestation process is not followed by a regrowth period at least over the last 3 years, it is considered as a Deforested land. Deforested land are also characterized by the recurrence of disruptions, i.e. the ratio between the number of years with at least one disruption observation and the total number of years between the first and last disruption observations. This information allowed to discriminate deforestation without prior degradation from deforestation occurring after degradation, the second one having a lower recurrence due to the 
441 period without any disruption between the degradation and deforestation phases (see

442 Supplementary Text on annual change dataset).

443 For the recent degradation and deforestation (class 4 ) that initiated in the last three years (after 444 year 2016) and that cannot yet be attributed to a long-term conversion to a non-forest cover, owing to the limited historical period of observation, specific rules were applied. Within this class, we separated degradation from deforestation, by taking a duration of minimum 366 days for the years 2017-2018 and a threshold of 10 disruptions for the last year (2019) to consider a deforested land.

A forest regrowth (class 5) is a two-phase transition from moist forest to (i) deforested land and then (ii) vegetative regrowth. A minimum 3-years duration of permanent moist forest cover presence is needed to classify a pixel as forest regrowth (to avoid confusion with agriculture).

The other land cover (class 6) includes savannah, deciduous forest, agriculture, evergreen shrubland and non-vegetated cover.

Finally, the Vegetation regrowth (class 7) consists of a transition from other land cover to to vegetation regrowth.

The third mapping step allowed to identify three sub-classes from the deforested land class. We geographically assigned deforestation to the conversion from TMF to tree plantations - mainly oil palm and rubber (class 2a), water surface (discriminating permanent and seasonal water)- mainly due to new dams (class 2 b), and other land cover - agriculture, infrastructures, etc. (class 2c) using ancillary spatial datasets completed by visual interpretation of high-resolution (HR) imagery (see Supplementary Text on ancillary data). Finally, we have re-assigned disturbances when detected within two geographically specific tropical forest formations: (i) the bamboo dominated forest, and 
465 (ii) the semi-deciduous transition tropical forest (Supplementary Text on specific tropical forest 466 formations).

Each disturbed pixel (degraded forest, deforested land, or forest regrowth) is characterized by the timing and intensity of the observed disruption events. The start and end dates of the disturbance allows identifying in particular the timing of creation of new roads or of logging activities and the age of forest regrowth or degraded forests. Three decadal periods have been used in the transition map to identify age sub-classes of degradation and forest regrowth: (i) before 2000, (ii) within 2000-2009 and (iii) within 2010-2019. The number of annual disruption observations combined with the duration, can be used as a proxy for the disturbance intensity and impact level.

In the last mapping step, we created a collection of 30 maps providing the spatial extent of the TMF and disturbance classes on a yearly basis, from 1990 to 2019, using dedicated decision rules (see Supplementary Text on the annual change dataset and thematic maps). These maps were used in our annual trend analysis -described in next subsection- to document the annual disturbances over the full period, with ten classes of transition for each annual statistic (Figs. 3 and 4, figs. S1 and S11): (i) degradation that occurs before deforestation, (iii) short-duration degradation not followed by deforestation, (iv) long-duration degradation not followed by deforestation, (v) direct deforestation (without prior degradation) not followed by forest regrowth, (vi) direct deforestation followed by forest regrowth, (viii) deforestation after degradation followed by forest regrowth, (viii) deforestation after degradation not followed by regrowth, (ix) forest conversion to water bodies and $(\mathrm{x})$ forest conversion to tree plantations. The associated metadata information on invalid observations within the forest domain and the proportion of invalid observations over the forest domain area were also documented. 
490 In order to produce a more conservative map of undisturbed forests by excluding potential missed 491 areas impacted by logging activities, we created a disturbance buffer zone using a threshold distance 492 of $120 \mathrm{~m}$ around disturbed pixels. This distance corresponds to the average observed distance between two logging desks (landing) and is consistent with the distances used in previous studies for assessing intact forests (15).

\section{Trend analysis}

497 The areas of TMF and disturbance classes are reported yearly and at 5-year intervals between 1990 and 2019, by country, subregion and continent (Tables 1, 2, and 3, Figs. 3 and 4 and fig. S11,

Supplementary Text on Trend analysis), using the country limits from the Global Administrative Unit Layers dataset from the FAO (53). Area measurements were also computed for $1^{\circ} \times 1^{\circ}$ cells of a systematic latitude-longitude grid in order to delineate hotspot areas of deforestation and degradation for the three decades (Fig. 5). For the three most recent years of the considered period (i.e. for 2017-2019), the proportions of disturbance types (degradation followed by deforestation, degradation not followed by deforestation and direct deforestation) were calibrated with historical proportions (2005-2014) of the three types of disturbances.

For countries with moist forest areas larger than 5 million ha in 1990 (i.e. for 32 countries), and for all sub regions, we analyzed the temporal dynamics of annual changes from 1990 to 2019 (fig. S11 and Supplementary Text on trend analysis).

\section{Validation}

The performance of our classifier was assessed in term of errors of omission and commission at the 512 pixel scale and the uncertainties in the area estimates derived from the transition map were quantified (see Supplementary Text on the validation). A stratified systematic sampling scheme was used to create a reference dataset of 5250 sample plots of $3 \times 3$ pixels ( 0.81 ha plot size) (fig. 
515 S8). For each sample plot, Landsat images at several dates were visually interpreted, together with 516 the most recent HR images available from the Digital Globe or Bing collections, to create the 517 reference dataset. The dates of the Landsat images to be interpreted were selected to optimize the 518 assessment of the performance of our classifier as follows (fig. S9) ; (i) at least one random date within three successive key periods to verify the consistency of the temporal sequencing and the classifier performance across the main sensors (L5, L7 and L8), (ii) for the disturbed classes, the two dates corresponding to the first and last disruption observations were selected to assess the commission errors, and (iii) for the undisturbed forest class, at least one random date during the Global Forest Change (GFC) loss year (if existing) to assess omission errors. It resulted into the interpretation of two to four Landsat images for each sample plot, with a total of 14295 images. the two products. 
540 We synthesized the GFC multiannual product into four classes of forest cover changes from the 541 combination of the GFC annual layers of tree cover loss and gain over the period 2001-2019: (i) unchanged (no loss, no gain), (ii) at least one loss but no gain, (iii) at least one gain but no loss and (iv) at least one loss and one gain. A new version of the transition map with eight classes was created (through the combination with annual maps) to characterize the disturbances that occurred between 2001 and 2019: (i) undisturbed forest (at the end of 2019), (ii) old degradation or regrowth (initiated before 2001), (iii) old deforestation (before 2001), (iv) degradation initiated between 2001 and 2019, (v) direct deforestation initiated between 2001 and 2019, (vi) deforestation that follows a degradation and initiated between 2001 and 2019, (vii) regrowth initiated from 2001 (viii) other land cover.

A matrix of correspondences between the synthesized GFC map (four classes) and our reclassified transition map (eight classes) was then produced for each continent and for the pan-tropical region, where area estimates are compared (table S1). This comparison shows that our annual change dataset depicts 138.9 million ha of forest disturbances along the periods 2001-2019 that are not depicted in the GFC map (representing 59\% of the total area of our disturbances). This finding is corroborated by previous studies $(\mathbf{3 3}, \mathbf{3 1})$. In addition, 17.6 million ha and 3.2 million ha are depicted as a GFC loss whereas it is classified as old deforestation and degradation respectively (before 2001) in our TMF dataset. Amongst the disturbances that are not depicted by GFC, the highest disagreements concern the gradual processes such the degradation, the forest regrowth classes, and the deforestation that follows a degradation for which $75 \%, 67 \%$ and $59 \%$ respectively of our depicted areas are missing on the GFC map, whereas our direct deforestation class shows a good correspondence with the GFC map (60\%). The disagreement between our dataset and the GFC map is even higher for the changes within the mangroves with $83 \%$ difference. Mangroves are a key ecosystem within the TMF. We also observed a lower agreement for the disturbance classes in Africa ( $38 \%$ of our disturbances are depicted by GFC) compared to other continents $(40.9 \%$ and 
43.3\% for Asia and Latin America respectively). A higher underestimation of GFC loss in Africa compared to other continents has also been observed by Tyukavina et al. (31) using a sample-based analysis.

We observe higher discrepancies between GFC and our study for shorter and lower intensity events, i.e. (i) the average duration for the disturbances detected only by our approach is 6.7 years compared to 9.4 years for the disturbances captured by both approaches, and (ii) the average intensity (or total number of disruptions detected for each disturbance) for the disturbances detected only by our approach is 9.9 compared to 32.6 for the disturbances captured by both approaches.

The evolution of the discrepancies over time shows major differences between the period (20012010) where our annual change dataset depicts $61.4 \%$ more deforested areas, and the last decade (2010-2019) where GFC losses include all our deforestation areas and 5.7\% of our degradation areas (Table 4 and Fig. 4). This change in the last decade has also been observed in another study (56) and can be explained (i) by the differences of processing applied by GFC team before and after the year $2011 \quad$ (https://earthenginepartners.appspot.com/science-2013-globalforest/download_v1.3.html), and (ii) by the inclusion of burned areas in the GFC loss (particularly for the dry period of 2015-2016) that are mainly classified as degradation in our TMF dataset.

\section{Projection of future forest cover}

Temporal projections of future forest cover are provided for (i) undisturbed forest area and (ii) total forest area (undisturbed and degraded forests) per country (fig. S12. and table S8). We considered that the annual disturbed areas followed an independent log-normal distribution for each country, and we used a modified version of the Cox method to estimate the mean and the $95 \%$ confidence interval (58) of the distribution. We used these estimates on the last 10 years (period 2010-2019) to 
590 project disturbances over the period 2020-2050 under a business-as-usual scenario. Several metrics,

591 with their uncertainties, have been produced: (i) forest area at the end of 2050, (ii) percentage of remaining forest area at the end of 2050 compared with forest area at the end of 2019 and (iii) year corresponding to full disappearance of forest cover.

\section{Known limitations and future improvements}

Disturbances that affect less than the full pixel area ( 0.09 ha size), e.g. the removal of a single tree, are generally not included in our results because the impact of the spectral values of the pixel are not strong enough to be detected. However, in specific cases, where the impact on the forest canopy cover modifies significantly the spectral values within a single pixel, e.g. the opening of a narrow logging road $(<10 \mathrm{~m}$ wide) or the removal of several big trees, our approach can detect such disturbances.

612 The accuracy of the disturbance detections has been assessed in the validation exercise (see 613 Validation section and Supplementary Text on the validation). The assignment of the disturbance 614 types at any location improves as the number of valid observations increases. The meta- 
615 information documents (i) the annual number of valid observations (ii) the first year of valid 616 observation (fig. S15) and (iii) the start year of the monitoring period (fig. S18) at each pixel 617 location. This meta-information (in particular the number of valid observations) can be 618 considered as a proxy measure of confidence. Hence our estimates of changes in the regions 619 where the total number of valid observations is particularly low and/or the start year of the monitoring period is late (figs. S14, S15, S18ra), e.g. Gabon, Salomon Islands, La Reunion, should be considered with lower confidence. However, considering the geographic completeness of Landsat-8 coverage after year 2013 there is high confidence for the contemporary reported estimates.

Short-duration events are likely to be underestimated for regions with geographic and temporal discontinuities in the Landsat archive and/or with gaps caused by persistent cloud cover. This is the case of Africa which is poorly covered by Landsat acquisitions before year 2000 (fig. S16). In order to provide a more conservative estimate of the remaining undisturbed forested areas, we also produced another estimate of undisturbed forested areas using a buffer zone with a threshold distance of $120 \mathrm{~m}$ from the detected disturbed pixels to exclude the potentially edge-affected forest areas. Further contextual spatial analysis would be needed to better estimate the characteristics of fragmented areas.

For the first time at pan tropical scale, a fine spatial resolution and annual frequency, detailed information on the historical forest area changes within the plantation concessions of oil palm and rubber are provided through to the combination of ancillary information and dedicated visual interpretation (see Supplementary Text on ancillary datasets). Although some confusion between forests and old plantations may remain (in particular for plantations that are not included in the ancillary database of concessions or that cannot be easily identified visually on satellite imagery 
640 from a regular geometrical shape), such errors are expected to be limited due to the consideration 641 of (i) a minimum duration for the initial period and (ii) a long observation period. Classes of tree 642 plantations do not include all commodities such as coffee, tea and coconut, that are detected as 643 deforested land (if initially TMF and converted in commodity during the monitoring period) or 644 other land cover (if the concession was already established during the initial period). leads - potentially - to a different transition class.

This approach can be automatically applied to future Landsat data (from 2020) and is intended to be adapted to Sentinel 2 data (available since 2015) towards a monitoring of tropical moist forests with higher temporal frequency and finer spatial resolution. 


\section{SUPPLEMENTARY MATERIALS}

This file contains Supplementary Text on ancillary data, on specific tropical forest formations, on the transition map, on the annual change dataset, on the validation, on the trend analysis, supplementary references, supplementary figures and supplementary tables.

\section{REFERENCES}

1. Gibson, L., Lee, T. M., Koh, L. P., Brook, B. W., Gardner, T. A., Barlow, J., Peres, C. A., Bradshaw, C. J. A., Laurance, W. F., Lovejoy, T. E., Sodhi, N. S. Primary forests are irreplaceable for sustaining tropical biodiversity. Nature 478, 378-381 (2011). doi:10.1038/nature10425

2. Watson, J. E. M. , Evans, T., Venter, O., Williams, B., Tulloch, A., Stewart, C., Thompson, I., Ray, J. C., Murray, K., Salazar, A., McAlpine, C., Potapov, P., Walston, J., Robinson, ., J. G., Painter, M., Wilkie, D., Filardi, C., Laurance, W. F., Houghton, R. A., Maxwell, S., Grantham, H., Samper, C., Wang, S., Laestadius, L., Runting, R. K., Silva-Chávez, G. A., Ervin, J., Lindenmayer, D. The exceptional value of intact forest ecosystems. Nature Ecology \& Evolution 2, 599-610 (2018). Doi:10.1038/s41559-018-0490-x

3. Mackey, B., DellaSala, D. A., Kormos, C., Lindenmayer, D., Kumpel, N., Zimmerman, B., Hugh, S., Young, V., Foley, S., Arsenis, K., Watson, J. E. M. Policy options for the world's primary forests in multilateral environmental agreements. Conserv. Lett. 8, 139-147 (2015). doi:10.1111/conl.12120

4. Luyssaert, S., Schulze, E.-D., Börner, A., Knohl, A., Hessenmöller, D., Law, B. E., Ciais, P., Grace, J. Old-growth forests as global carbon sinks. Nature 455, 213-215 (2008). doi: $10.1038 /$ nature 07276

5. Aerts, R., Honnay, O. Forest restoration, biodiversity and ecosystem functioning. BMC Ecology, 11, 1-10 (2011). doi:10.1186/1472-6785-11-29 
6. Alkama, R., Cescati, A. Biophysical climate impacts of recent changes in global forest cover. Science 351, 600-604 (2016). doi:10.1126/science.aac8083.

7. Grassi, G., House, J., Dentener, F., Federici, S., den Elzen, M., Penman, J. Key role of forests in meeting climate targets but science needed for credible mitigation. Nature Climate Change 7, 220-226 (2017). doi:10.1038/NCLIMATE3227

8. Barlow, J., Lennox, G.D., Ferreira, J., Berenguer, E., Lees, A. C., Mac Nally, R., Thomson, J. R., Frosini de Barros Ferraz, S., Louzada, J., Fonseca Oliveira, V. H., Parry, L., Ribeiro de Castro Solar, R., Vieira, I. C. G., Aragão, L. E. O. C., Anzolin Begotti, R., Braga, R. F., Moreira Cardoso, T., Cosme de Oliveira Jr, R., Souza Jr, C. M., Moura, N. G., Serra Nunes, S., Victor Siqueira, J., Pardini, R., Silveira, J. M., Vaz-de-Mello, F. Z., Carlo Stulpen Veiga, R., Venturier, A., Gardner, T. A. Anthropogenic disturbance in tropical forests can double biodiversity loss from deforestation. Nature 535, 144-147 (2016). doi:10.1038/nature18326

9. Strona, G., Stringer, S. D., Vieilledent, G., Szantoi, Z., Garcia-Ulloa, J., Wich, S., Small room for compromise between oil palm cultivation and primate conservation in Africa. Proc. Natl. Acad. Sci. U.S.A., 115: 8811-8816 (2018). doi: 10.1073/pnas.1804775115

10. Mitchard, E.T.A. The tropical forest carbon cycle and climate change, Nature, 559, 527-534 (2018).

11. Laurance, W. F., Goosem, M., Laurance, S. G. W. Impacts of roads and linear clearings on tropical forests. Trends Ecol. Evol. 24:659-669 (2009). doi:10.1016/j.tree.2009.06.009.

12. Brienen, R., Phillips, O., Feldpausch, T., Gloor, E., Baker, T., Lloyd, J., Lopez-Gonzalez, G., Monteagudo-Mendoza, A., Malhi, Y., Lewis, S. et al., Long-term decline of the Amazon carbon sink Nature, Nature Publishing Group, 519, 344-348, (2015).

13. Baccini, A., Walker, W., Carvalho, L., Farina, M., Sulla-Menashe, D., Houghton, R. A. Tropical forests are a net carbon source based on aboveground measurements of gain and loss. Science 358, 230-234 (2017). doi:10.1126/science.aam5962 
14. Brinck, K., Fischer, R., Groeneveld, J., Lehmann, S., Dantas De Paula, M., Pütz, S., Sexton, J. O., Song, D., Huth, A. High resolution analysis of tropical forest fragmentation and its impact on the global carbon cycle. Nat. Commun. 8, 14855 (2017). doi:10.1038/ncomms 14855

15. Qie, L., Lewis, S.L., Sullivan, M.J.P., Lopez-Gonzalez, G., Pickavance, G.C., Sunderland, T., Ashton, P., Hubau, W., Abu Salim, K., Aiba, S-I., Banin, L.F., Berry, N., Brearley, F.Q., Burslem, D.F.R.P., Dančák, M., Davies, S.J., Fredriksson, G., Hamer, K.C., Hédl, R., Kho, L.K., Kitayama , K, Krisnawati , H , Lhota , S , Malhi , Y, et al. Long-term carbon sink in Borneo's forests halted by drought and vulnerable to edge effects. Nat. Commun. 8, 1966 (2017) doi: 10.1038/s41467-017-01997-0

16. Pütz, S., Groeneveld, J., Henle, K., Knogge, C., Camargo Martensen, A., Metz, M., Metzger, J. P., Cezar Ribeiro, M., Dantas de Paula, M., Huth, A. Long-term carbon loss in fragmented Neotropical forests. Nature Communications 5, 5037 (2014). doi:10.1038/ncomms6037

17. Fu, Z., Li, D., Hararuk, O., Schwalm, C., Luo, Y., Yan, L., Niu, S. Recovery time and state change of terrestrial carbon cycle after disturbance. Environ. Res. Lett. 12, 104004 (2017). doi:10.1088/1748-9326/aa8a5c

18. Olivero, J., Fa, J. E., Real, R., Márquez, A. L., Farfán, M. A., Vargas, J.M. et al. (2017). Recent loss of closed forests is associated with Ebola virus disease outbreaks. Scientific Reports, 7, 14291. https://doi.org/10.1038/s41598-017-14727-9

19. Rulli, M.C., Santini, M., Hayman, D.T.S. and D'Odorico, P. (2017). The nexus between forest fragmentation in Africa and Ebola virus disease outbreaks. Scientific Reports, 7, 41613. https://doi.org/10.1038/srep41613

20. MacDonald, A.J., and Mordecai, E.A., Amazon deforestation drives malaria transmission, and malaria burden reduces forest clearing. PNAS, 116, 22212-22218 (2019). https://doi.org/10.1073/pnas.1905315116 
21. Potapov, P., Hansen, M.C., Laestadius, L., Turubanova, S., Yaroshenko, A., Thies, C., Smith, W., Zhuravleva, I., Komarova, A., Minnemeyer, S. et al. The last frontiers of wilderness: Tracking loss of intact forest landscapes from 2000 to 2013. Sci. Adv. 3, (2017). doi:10.1126/sciadv.1600821

22. Gorelick, N., Hancher, M., Dixon, M., Ilyushchenko, S., Thau, D., Moore, R. Google Earth Engine: Planetary-scale geospatial analysis for everyone. Remote Sens. Environ. 202, 18-27 (2017). Doi:10.1016/j.rse.2017.06.031

23. Woodcock, C.E. , Allen, R., Anderson, M., Belward, A., Bindschadler, R., Cohen, W., Gao, F., Goward, S.N., Helder, D., Helmer, E., Nemani, R., Oreopoulos, L., Schott, J., Thenkabail, P.S., Vermote, E.F., Vogelmann, J., Wulder, M.A., Wynne, R. Free access to Landsat imagery. Science 320, 1011 (2008). doi:10.1126/science.320.5879.1011a

24. Hansen, M. C., Potapov, P.V., Moore, R., Hancher, M., Turubanova, S.A., Tyukavina, A., Thau, D., Stehman, S.V., Goetz, S.J., Loveland, T.R. et al. High-resolution global maps of 21st-century forest cover change. Science 342, 850-853 (2013). Doi:10.1126/science.1244693

25. Kim, D.-H., Sexton, J. O., Noojipady, P., Huang, C., Anand, A., Channan, S., Feng, M., Townshend, J.R. Global, Landsat-based forest-cover change from 1990 to 2000. Remote Sensing of Environment 155, 178-193 (2014). Doi:10.1016/j.rse.2014.08.017

26. Olofsson, P., Foody, G. M., Herold, M., Stehman, S. V., Woodcock, C. E., Wulder, M.A. Good practices for estimating area and assessing accuracy of land change. Remote Sens. Environ. 148, 42-57 (2014).

27. Fonseca, M. G., Anderson, L.O., Arai, E., Shimabukuro, Y. E., Xaud, H. A. M., Xaud, M. R., Madani, N., Wagner, F. H., Aragão, L.E.O.C. Climatic and anthropogenic drivers of northern Amazon fires during the 2015/2016 El Niño event. Ecological Applications 27, 2514-2527 (2017). Doi:10.1002/eap.1628 
28. Aragão, L.E.O.C., Anderson, L.O., Fonseca, M.G., Rosan, T.M., Vedovato, L.B., Wagner, F. H., Silva, C. V. J., Silva Junior, C. H. L., Arai, E., Aguiar, A. P., Barlow, J., Berenguer, E., Deeter, M. N., Domingues, L. G., Gatti, L., Gloor, M., Malhi, Y., Marengo, J.A., Miller, J.B., Phillips, O.L., Saatchi, S. 21st Century drought-related fires counteract the decline of Amazon deforestation carbon emission. Nature Communications 9,536 (2018).

29. Jiménez-Muñoz, J. C., Mattar, C., Barichivich, J., Santamaría-Artigas, A.,Takahashi, K., Malhi, Y., Sobrino, J. A., van der Schrier, G. Record-breaking warming and extreme drought in the Amazon rainforest during the course of El Niño 2015-2016. Sci. Rep. 6, 33130 (2016) doi: $10.1038 /$ srep33130

PRODES (http://www.obt.inpe.br/OBT/assuntos/programas/amazonia/prodes)

30. Keenan, R. J., Reams, G.A., Achard, F., de Freitas, J.V., Grainger, A., Lindquist, E., Dynamics of global forest area: Results from the FAO Global Forest Resources Assessment 2015. Forest Ecology and Management 352, 9-20 (2015). doi:10.1016/j.foreco.2015.06.014

31. Tyukavina, A., Baccini, A., Hansen, M.C., Potapov, P.V., Stehman, S.V., Houghton, R.A., Krylov, A.M., Turubanova, S., Goetz, S.J. Aboveground carbon loss in natural and managed tropical forests from 2000 to 2012. Environ. Res. Lett. 10, 074002 (2015). doi:10.1088/1748$9326 / 10 / 7 / 074002$

32. Achard, F., Beuchle, R., Mayaux, P., Stibig, H-J., Bodart, C., Brink, A., Carboni, S., Desclée, B., Donnay, F., Eva, H.D., Lupi, A., Raši, R., Seliger, R., Simonetti, D. Determination of tropical deforestation rates and related carbon losses from 1990 to 2010. Glob. Chang. Biol. 20, 2540-2554 (2014). doi:10.1111/gcb.12605

33. Tropek, R., Sedláček, O., Beck, J., Keil, P., Musilová, Z., Šímová, I., Storch, D. Comment on "High-resolution global maps of 21st-century forest cover change". Science 344, 981 (2014). 
34. Finer, M., Novoa, S., Weisse, M. J., Petersen, R., Mascaro, J., Souto, T., Stearns, F., García Martinez R., Combating deforestation: From satellite to intervention. Science 360, 1303-1305 (2018). doi:10.1126/science.aat1203.

35. Whitmore, T.C. An introduction to tropical rain forests. Oxford: Clarendon (1990).

36. FAO, Global Ecological Zones for FAO forest reporting: 2010 Update (U.N. Food and Agriculture Organization, 2012). (http://www.fao.org/geonetwork/srv/en/main.home)

37. Wulder, M. A., Masek, J. G., Cohen, W. B., Loveland, T. R., Woodcock, C. E. Opening the archive: How free data has enabled the science and monitoring promise of Landsat. Remote Sens. Environ. 122, 2-10 (2012). doi:10.1016/j.rse.2012.01.010

38. Markham, B. L., Storey, J. C., Williams, D. L., Irons, J. R. Landsat sensor performance: history and current status. IEEE Transactions on Geoscience and Remote Sensing 42, 2691-2694 (2004).

39. Goward, S., Arvidson, T., Williams, D., Faundeen, J., Irons, J., Franks, S. Historical Record of Landsat Global Coverage Mission Operations, NSLRSDA, and International Cooperator Stations. Photogrammetric Engineering \& Remote Sensing 72, 1155-1169 (2006).

40. Chen, J., Zhu, X., Vogelmann, J.E., Gao, F., Jin, S. A simple and effective method for filling gaps in Landsat ETM+ SLC-off images. Remote Sens. Environ. 115, 1053-1064 (2011). doi:10.1016/j.rse.2010.12.010

41. Pekel, J.-F., Cottam, A., Gorelick, N., Belward, A. S. High-resolution mapping of global surface water and its long-term changes. Nature 540, 418-422 (2016). doi: 10.1038/nature20584

42. Keim, D. A. et al. in Visual Data Mining 76-90, http://kops.unikonstanz.de/bitstream/handle/123456789/5631/Visual_Analytics_Scope_and_Challenges.p $\underline{\mathrm{d}}$ ? sequence $=1 \&$ is Allowed $=\mathrm{y}($ Springer, 2008).

43. Yang, J.-B. \& Xu, D. L. On the evidential reasoning algorithm for multiple attribute decision analysis under uncertainty. IEEE Trans. Syst. Man Cybern. A 32, 289-304 (2002). 
44. Roy, D. P., Ju, J., Kline, K., Scaramuzza, P.L., Kovalskyy, V., Hansen, M. C., Loveland, T.R, Vermote, E., Zhang, C. Web-Enabled Landat Data (WELD): Landsat ETM+ composited Mosaics of the Conterminous United States. Remote Sens. Environ. 114, 35-49 (2010). doi:10.1016/j.rse.2009.08.011

45. Potapov, P. V., Turubanova, S. A., Hansen, M. C., Adusei, B., Broich, M., Altstatt, A., Mane, L., Justice, C.O. Quantifying forest cover loss in Democratic Republic of the Congo, 20002010, with Landsat ETM+ data. Remote Sens. Environ. 122, 106-116 (2012) doi:10.1016/j.rse.2011.08.027

46. Margono, A., Turubanova, S., Zhuravleva, I., Potapov, P., Tyukavina, A., Baccini, A., Goetz, S., Hansen, M. C. Mapping and monitoring deforestation and forest degradation in Sumatra (Indonesia) using Landsat time series data sets from 1990 to 2010. Environmental Research Letters 7, 034010 (2012). doi:10.1088/1748-9326/7/3/034010

47. Griffiths, P., Kuemmerle, T., Baumann, M., Radeloff, V.C., Abrudan, I.V., Lieskovsky, J., Munteaunu, C., Ostapowicz, K., Hostert, P. Forest disturbances, forest recovery, and changes in forest types across the Carpathian ecoregion from 1985 to 2010 based on Landsat Image Composites. Remote Sens. Environ. 151, $72-88$ (2014). doi:101016/j.rse.2013.04.022

48. Potapov, P. V., Turubanova, S. A., Tyukavina, A., Krylov, A. M., McCarty, J. L., Radeloff, V. C., Hansen, M. C. Eastern Europe's forest cover dynamics from 1985 to 2012 quantified from the full Landsat archive. Remote Sens. Environ. 159, 28-43 (2015). doi:10.1016/j.rse.2014.11.027

49. Muller, H., Griffiths, P., Hostert, P. Long-term deforestation dynamics in the Brazilian Amazon - Uncovering historic frontier development along the Cuiabá-Santarém highway. International Journal of Applied Earth Observation and Geoinformation 44, 61-69 (2016). doi: 10.1016/j.jag.2015.07.005 
50. Hermosilla, T., Wulder, M. A., White, J.C., Coops, N .C.,, Hobard, G. W. Updating Landsat time series of surface-reflectance composites and forest change products with new observations. International Journal of Applied Earth Observation and Geoinformation 63, 104-111 (2017). doi: 10.1016/j.jag.2017.07.013

51. Pekel, J.-F. Vancutsem, C., Bastin, L., Clerici, M., Vanbogaert, E., Bartholomé, E., Defourny, P. A near real-time water surface detection method based on HSV transformation of MODIS multi-spectral time series data. Remote Sens. Environ. 140, 704-716 (2014). doi.org/10.1016/j.rse.2013.10.008

52. Smith, A. R. Color gamut transform pairs. Comput. Graph. 12, 12-19 (1978).

53. FAO, Global Administrative Unit Layers (GAUL) (http://www.fao.org/geonetwork/srv/en/main.home)

54. Sanderson, E. W., Jaiteh, M., Levy, M. A., Redford, K. H., Wannebo, A. V., Woolmer, G. The human footprint and the last of the wild. Bioscience 52, 891-904 (2002). Doi:10.1641/0006$3568(2002) 052$

55. Thompson, I., Guariguata, M.R, Okabe, K., Bahamondez, C., Nasi, Heymell, R., Sabogal S., An Operational Framework for Defining and Monitoring Forest Degradation. Ecology and Society 18(2):20 (2013). doi: 10.5751/ES-05443-180220

56. Galiatsatos, N. Donoghue, D.N.M., Watt, P., Bholanath, P., Pickering, J., Hansen, M.C. and Mahmood, A.R.J. An Assessment of Global Forest Change Datasets for National Forest Monitoring and Reporting. Remote Sens. 12, 1790 (2020).

57. Turubanova, S., Potapov, A.V., Tyukavina, A., Hansen, M.C., Ongoing primary forest loss in Brazil, Democratic Republic of the Congo, and Indonesia, Environ. Res. Lett. 13, (2018).

58. Olsson, U. Confidence intervals for the mean of a log-normal distribution. Journal of Statistics Education 13 (2005) 


\section{ACKNOWLEDGMENTS}

863 The USGS and NASA provided the Landsat imagery. R. Moore and her team provided the Google 864 Earth Engine. Noel Gorelick, Mike Dixon, and Chris Herwig provided support in GEE.

Andrew Cottam provided support for the validation tool (adaptation from the water surface validation tool). Andreas Langner, Hans-Jurgen Stibig, Rene Beuchle, Astrid Verhegghen, Hugh Eva, Rosana Grecci, and Baudouin Desclee provided a useful feedback on the legend and products in the framework of the ReCaREDD (Reinforcement of Capacities for REDD+) and REDDCopernicus projects. We thank Alessandro Cescatti and Philippe Mayaux for reviewing earlier versions of the manuscript.

This study was funded by the Directorate-General for Climate Action of the European Commission (DG-CLIMA) in the framework of the Roadless-For pilot project (Making efficient use of EU climate finance: Using roads as an early performance indicator for REDD+ projects).

\section{CONTRIBUTIONS}

$\mathrm{CV}$ was the principal investigator of this study. CV developed the expert system, implemented all the steps and analyzed the results. The manuscript was prepared by $\mathrm{CV}$ and FA, with the contributions of J-F.P., GV, JG, LA and RN. FA contributed to the analysis of the results. CV, FA and JG developed together the validation method. J-F.P contributed to the development of the expert system. GV realized the deforestation predictions, provided support with Python and gave a useful feedback on the maps produced. SC realized the validation exercise and contributed to the creation of the plantation database. DS gave a support for coding with GEE and Python. AM and DS realized the website. 
888 Fig. 1. Map of tropical moist forests remaining in January 2020 and disturbances observed during 889 the period 1990-2019. See legend in Fig. 2.
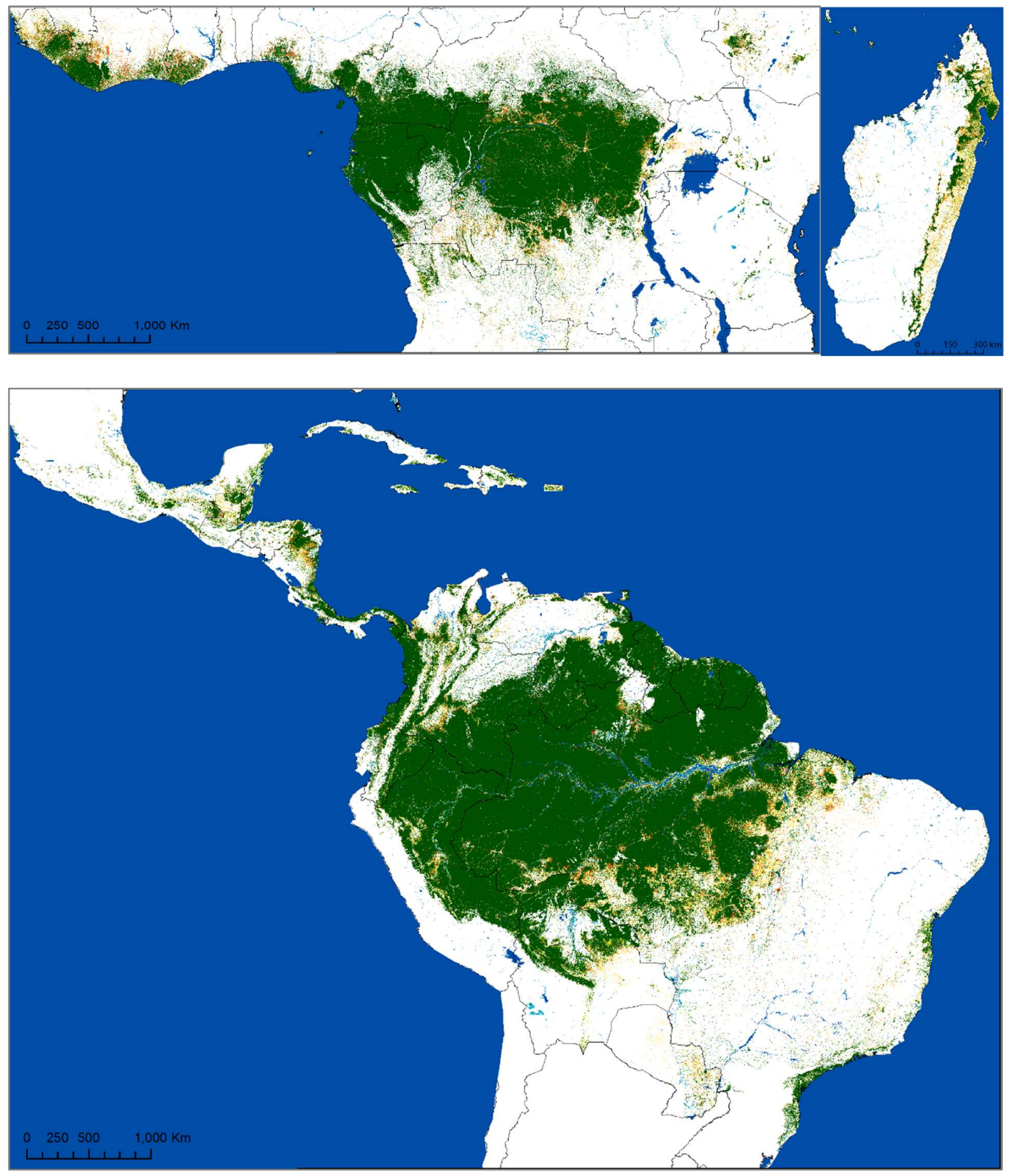


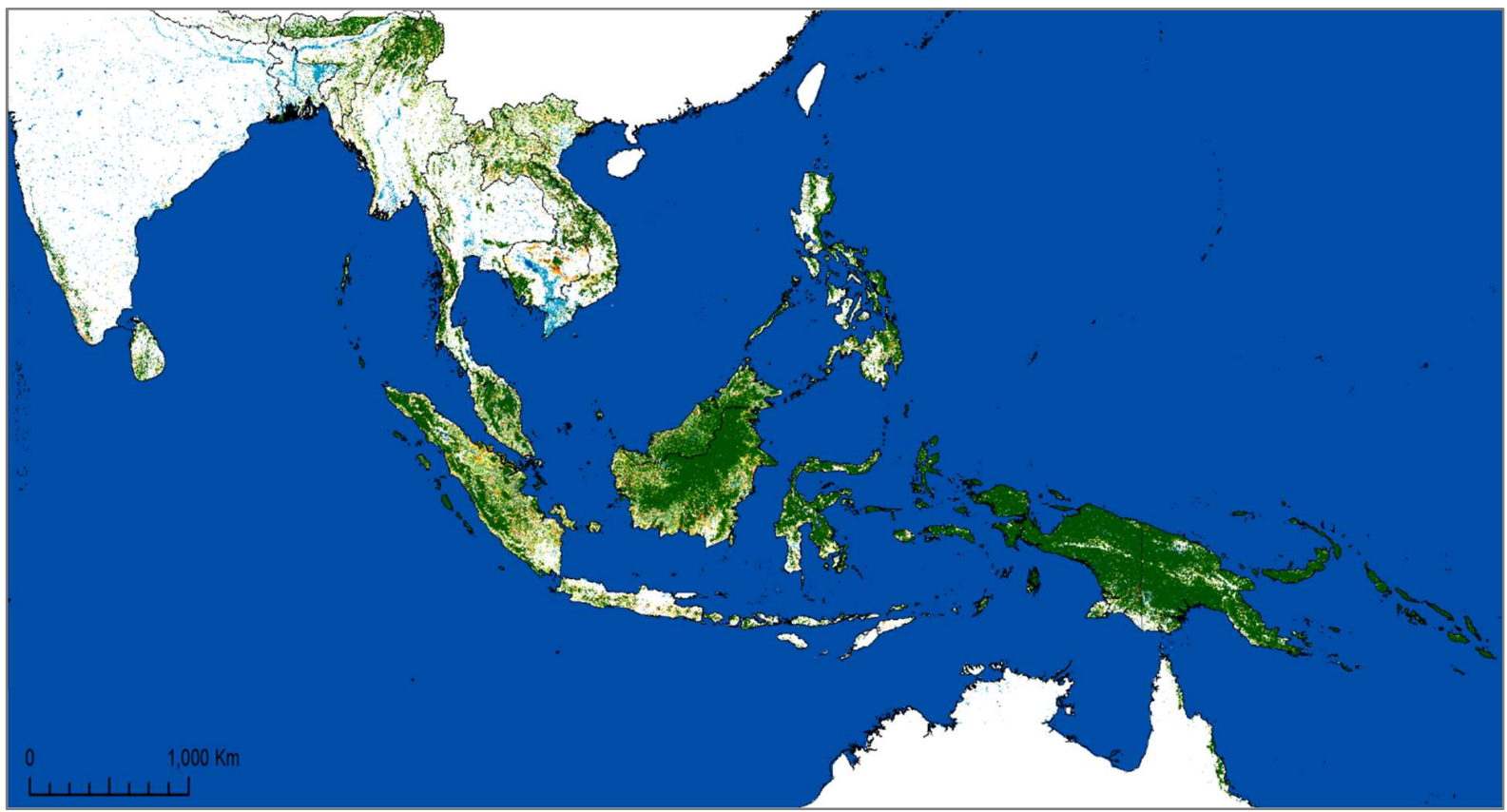


896 Fig. 2. Examples of patterns of forest cover disturbances (deforestation and degradation) during the 897 period 1990-2019 : (A) Remaining Mangroves and the related changes in Guinea-Bissau $\left(14.9^{\circ} \mathrm{W}\right.$, $\left.89811.1^{\circ} \mathrm{N}\right)$, (B) Fires in Mato-Grosso province of Brazil $\left(53.8^{\circ} \mathrm{W}, 13^{\circ} \mathrm{S}\right)$, (C) Recent deforestation in 899 Colombia $\left(74.4^{\circ} \mathrm{W}, 0.7^{\circ} \mathrm{N}\right)$, (D) Logging in Mato-Grosso $\left(54.5^{\circ} \mathrm{W}, 12^{\circ} \mathrm{S}\right)$, (E) Deforestation and 900 degradation caused by the railway in Cameroon $\left(13.4^{\circ} \mathrm{E}, 5.8^{\circ} \mathrm{N}\right)(\mathrm{F})$ Recent selective logging in 901 Ouesso region of Republic of Congo $\left(15.7^{\circ} \mathrm{E}, 1.4^{\circ} \mathrm{N}\right),(\mathrm{G})$ Deforestation for the creation of a dam 902 in Malaysia $\left(113.8^{\circ} \mathrm{E}, 2.4^{\circ} \mathrm{S}\right),(\mathrm{H})$ Massive deforestation in Cambodia $\left(105.6^{\circ} \mathrm{E}, 12.7^{\circ} \mathrm{N}\right)$, and (I) 903 Commodities in the Riau province of Indonesia $\left(102^{\circ} \mathrm{E}, 0.4^{\circ} \mathrm{N}\right)$. The size of each box is $20 \mathrm{~km} \times 20$ $904 \mathrm{~km}$
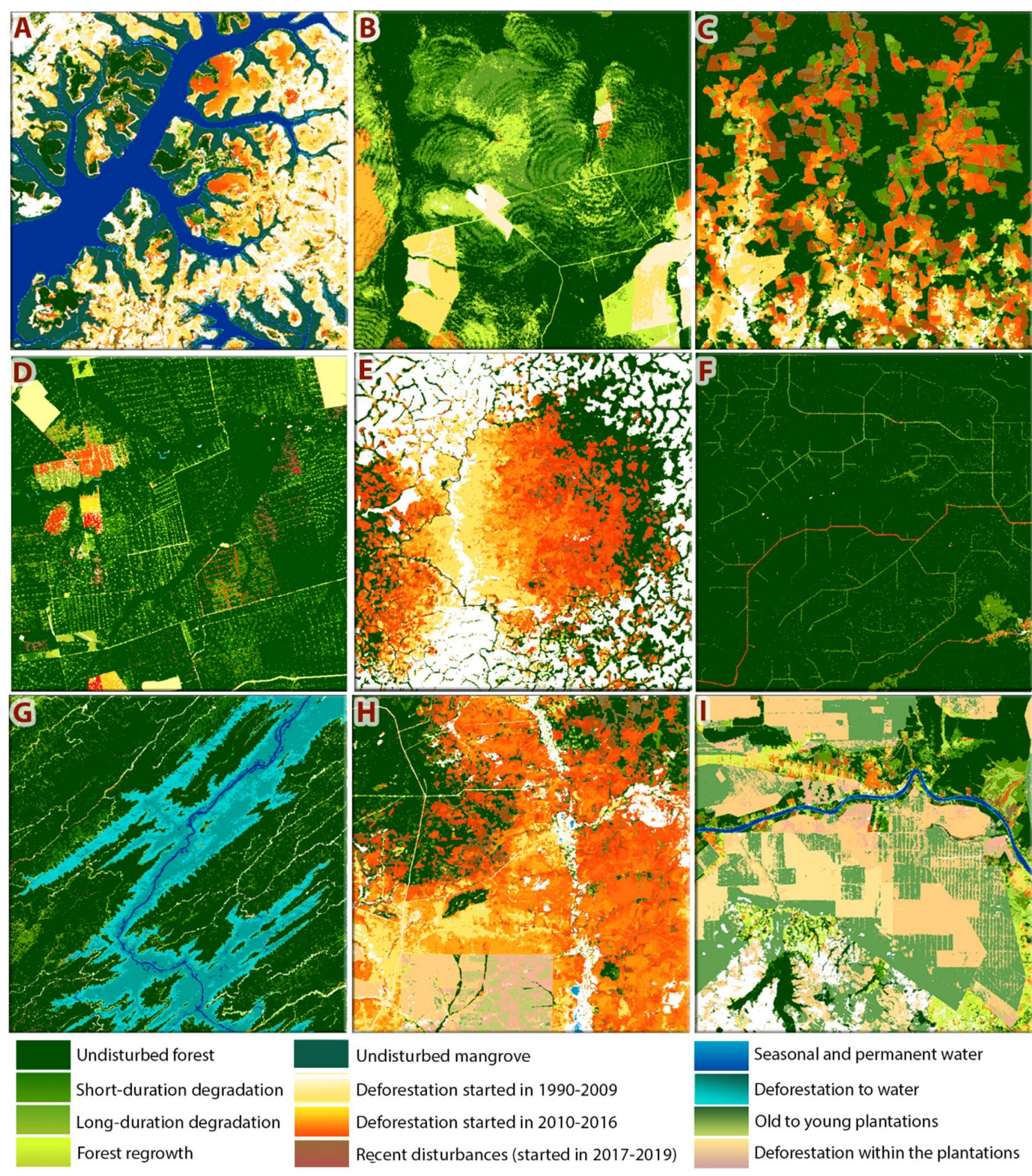

Undisturbed mangrove

Deforestation started in 1990-2009

Deforestation started in 2010-2016

Recent disturbances (started in 2017-2019) 
Fig. 3 Evolution of annual deforestation and degradation (A) over the last 25 years in South regions.

(A)

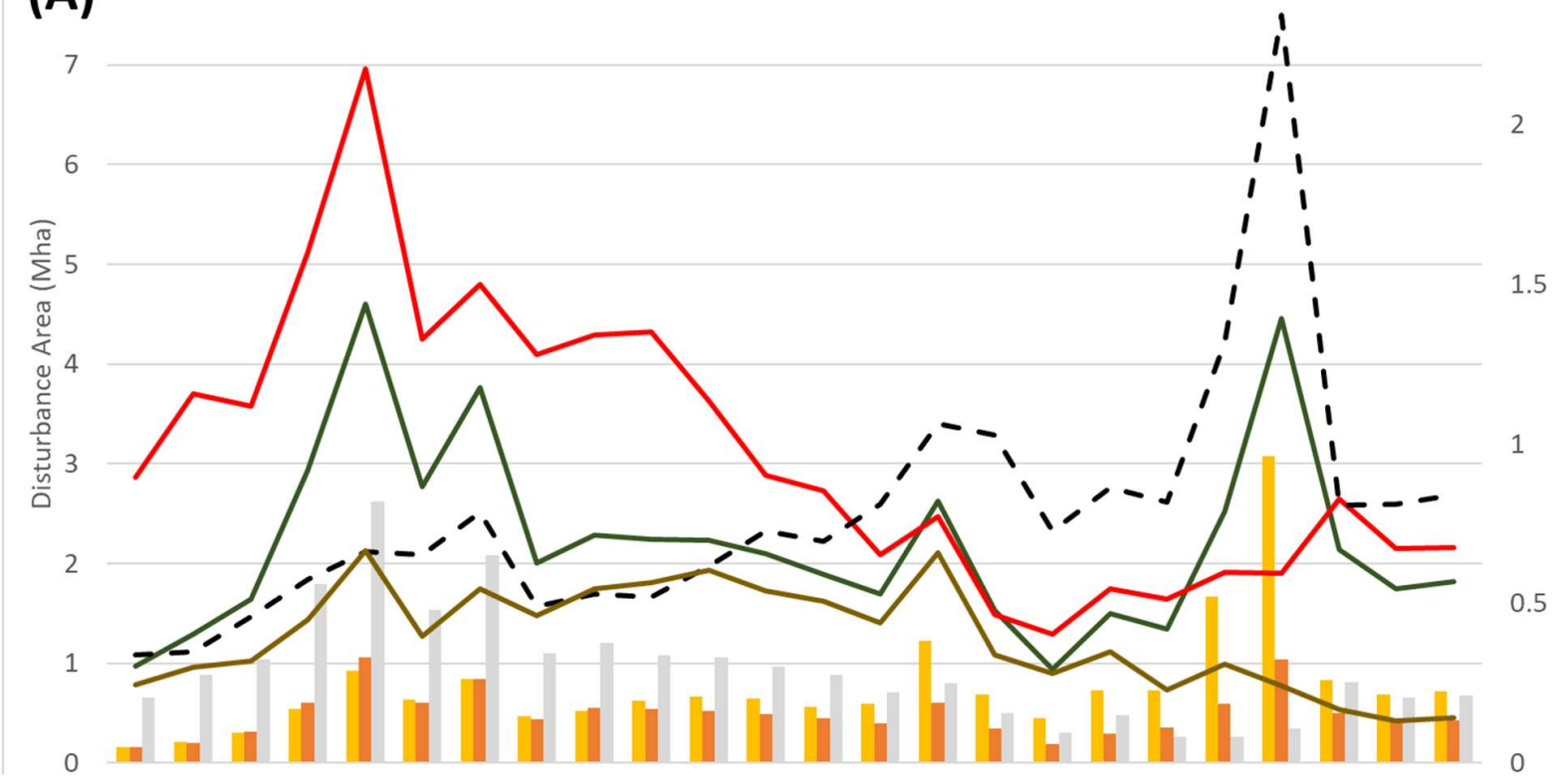

(B)
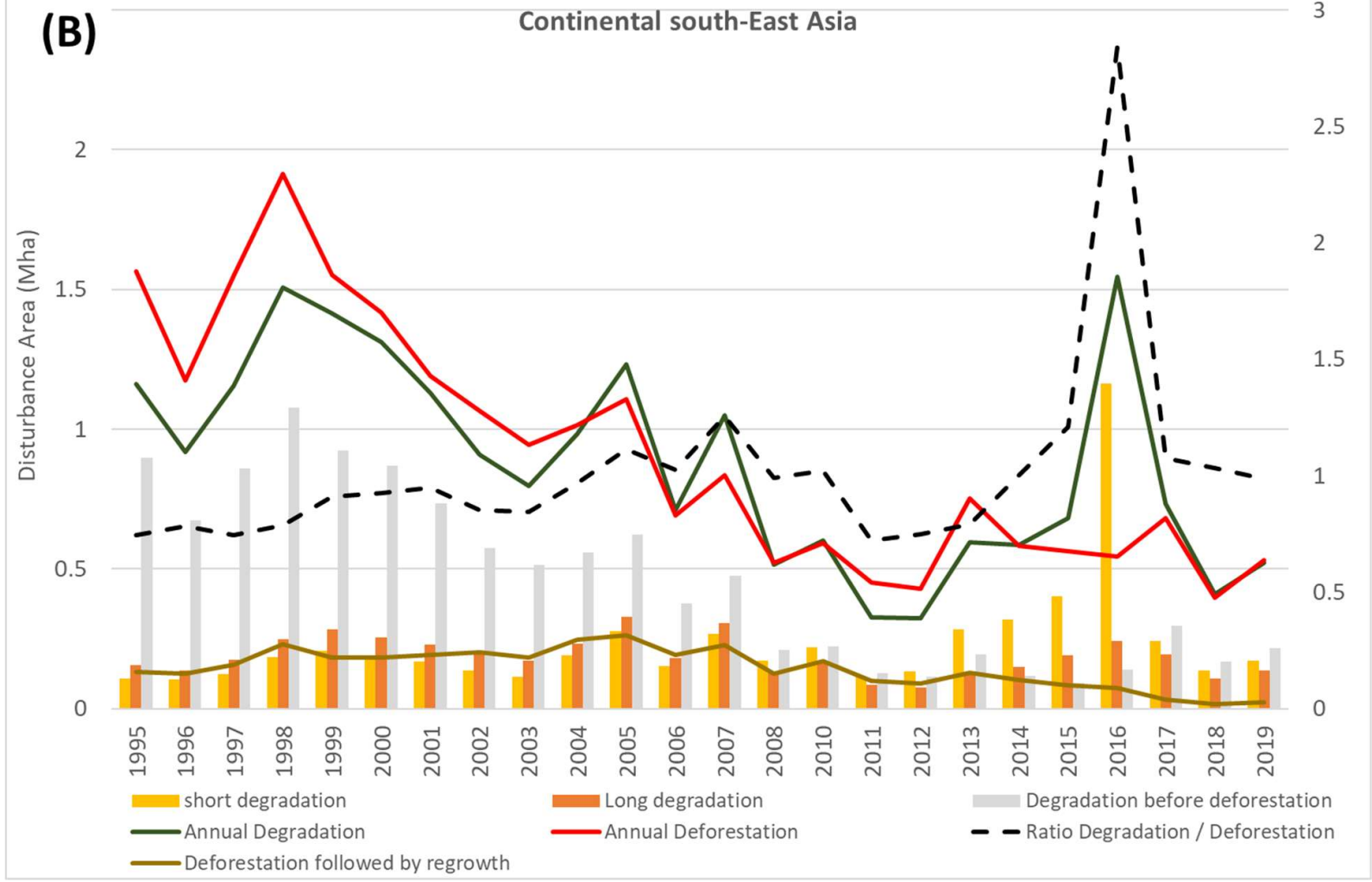


\section{(C)}

All regions

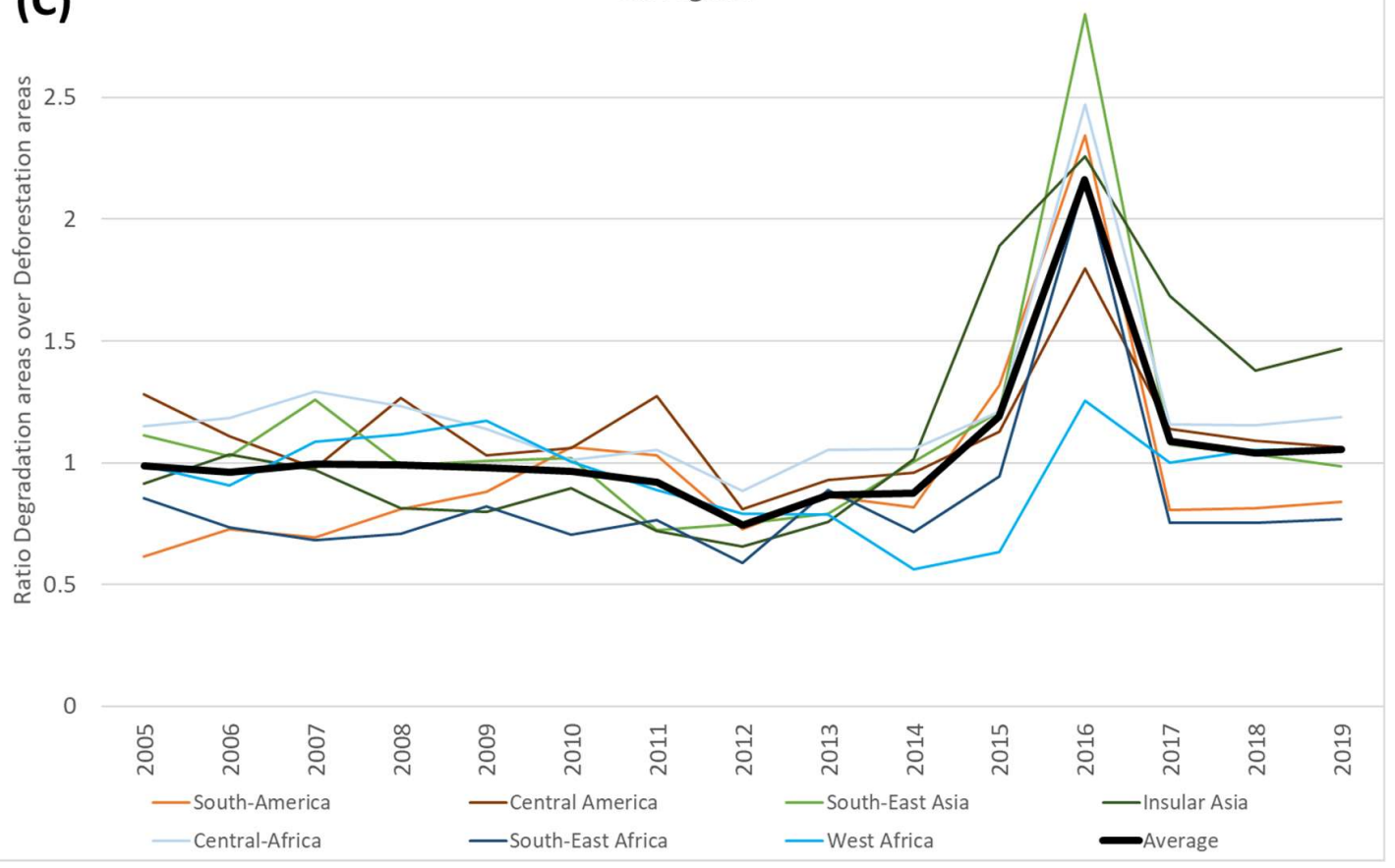


Fig. 4 Dynamics of annual disturbed areas from 2001 to 2019 for (A) the Amazônia Legal region of Brazil within the primary forest extent in 2000 from INPE and (B) Indonesia using the entire TMF extent (undisturbed and degraded) in 2000. (x-axis in years and y-axis in million ha) in comparison with GFC loss and the PRODES data for the Amazônia Legal region of Brazil. * The average proportions of disturbance types within total disturbances over the period 2005-2014 is used to distribute the disturbance types for years 2017 to 2019.
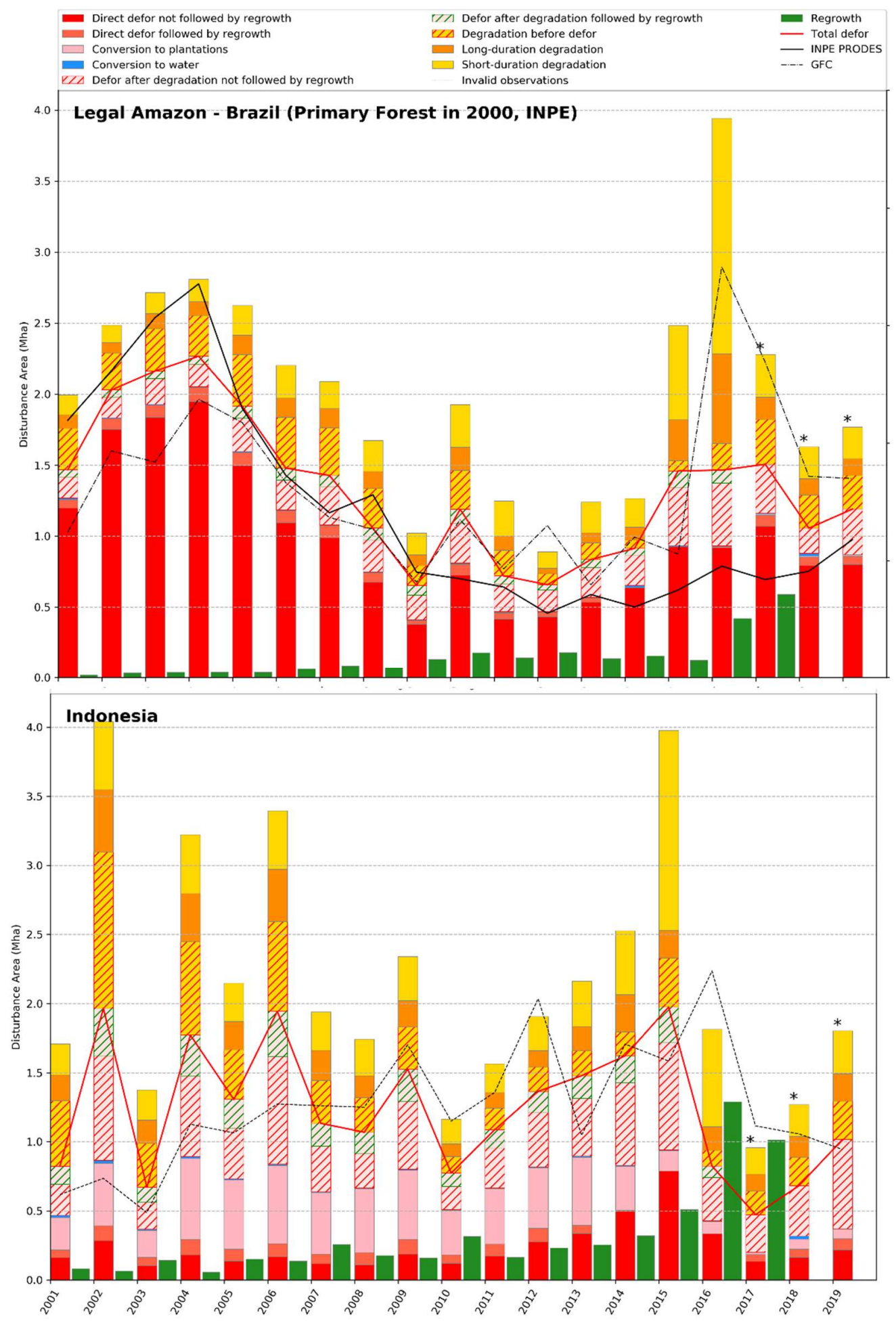
936 Fig. 5 Evolution of hotspots of deforestation (A) and degradation (B) during the last three decades 937 (total deforested or degraded area per box of $1^{\circ}$ latitude $\times 1^{\circ}$ longitude size - scale in million ha).

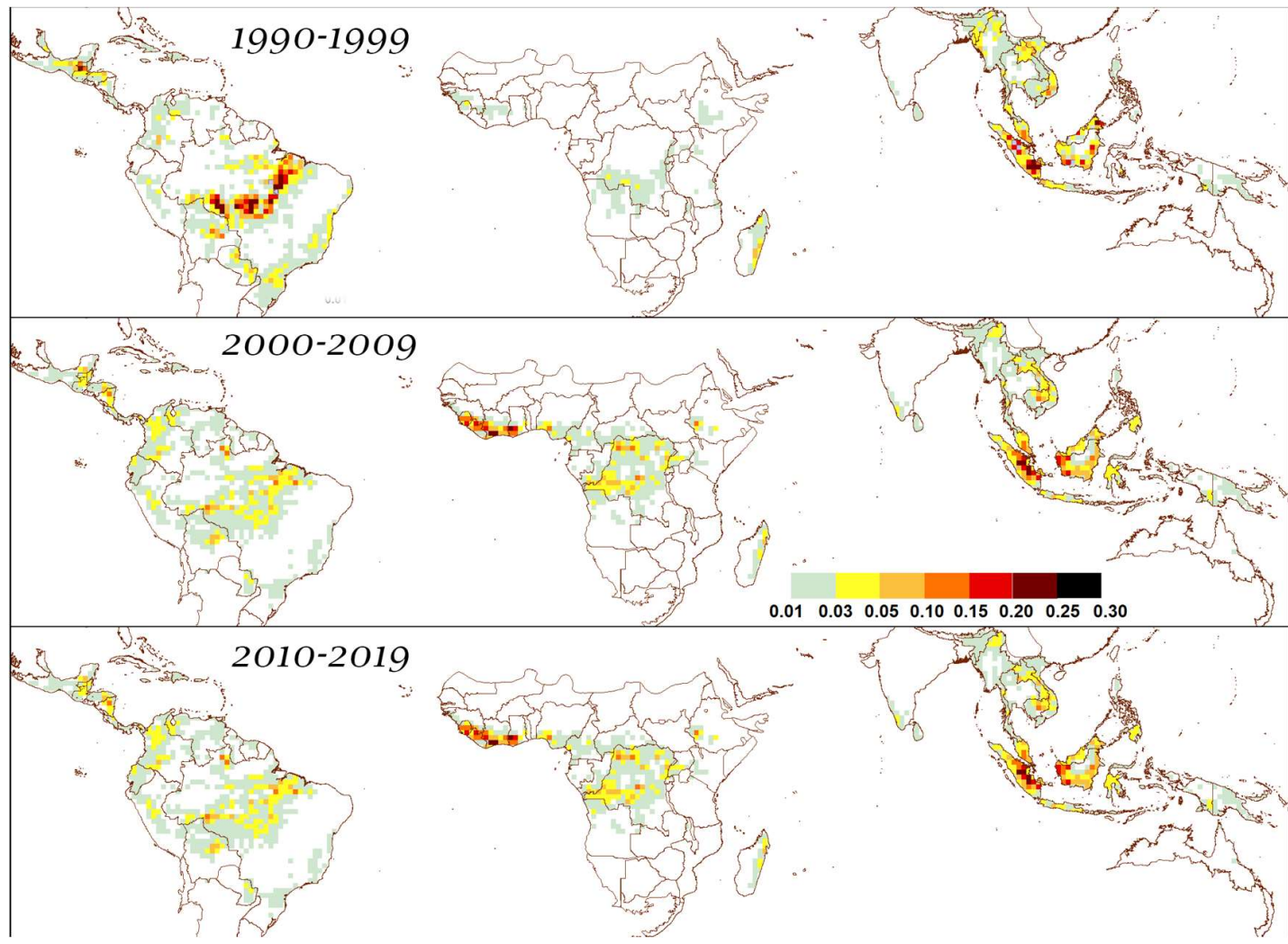

(B)

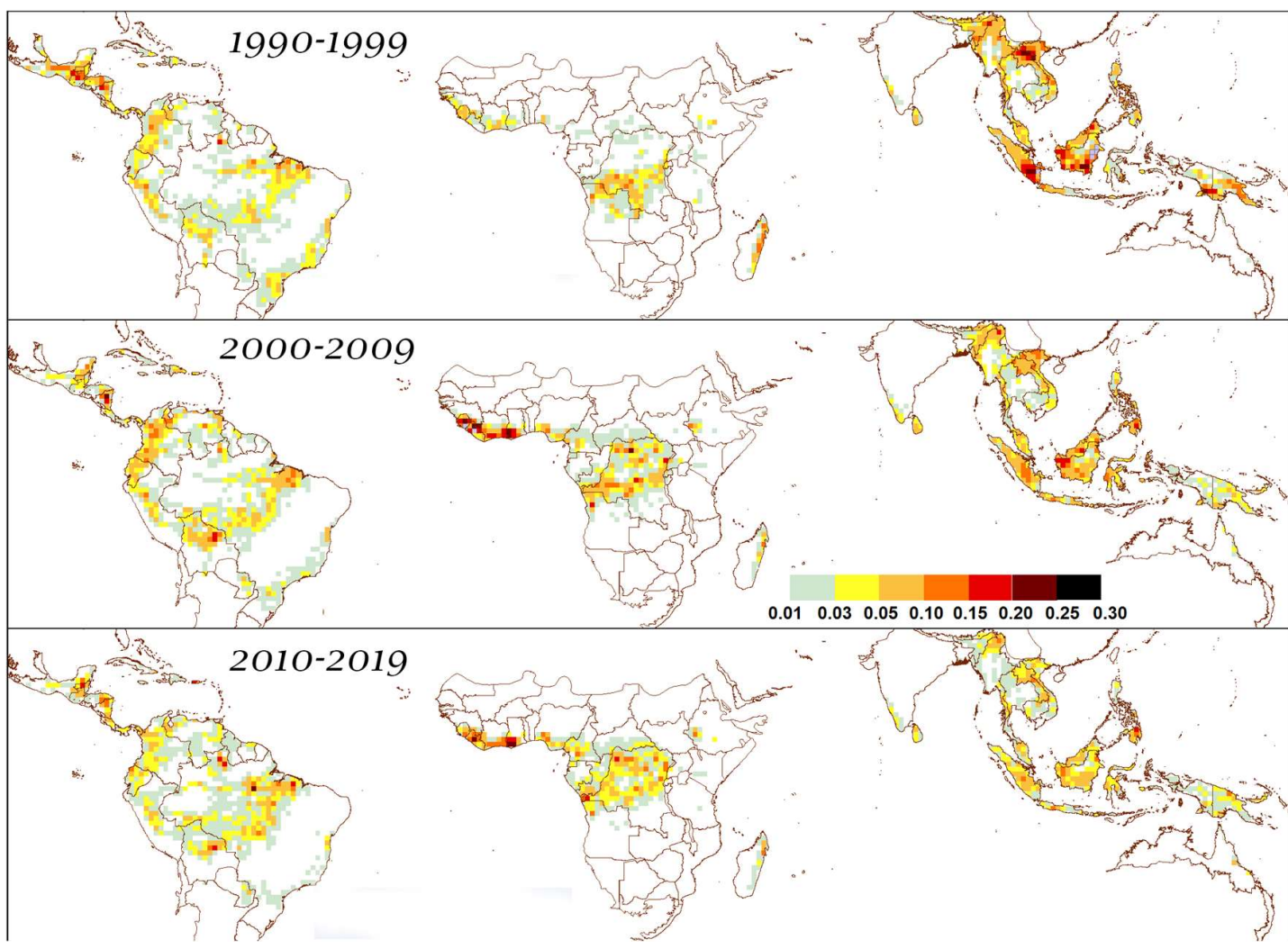


940 Table 1 Areas (in million ha) of (a) undisturbed tropical moist forests (TMF) and (b) Undisturbed 941 and degraded TMF for years 1990, 1995, 2000, 2005, 2010, 2015 and 2020 (on first January) by 942 sub-region and continent, and relative decline (in \%) over intervals of 30 years (1990-2020), and 94310 years $(1990-2000,2000-20100,2010-2020)$. The values appearing in grey color indicate values 944 derived from an average percentage of invalid pixel observations over the baseline TMF domain 945 higher than $40 \%$.

$946 \quad$ (a)

\begin{tabular}{|l|c|c|c|c|c|c|c|c|c|c|c|}
\hline \multicolumn{1}{c|}{} & \multicolumn{9}{|c|}{ Area of Undisturbed TMF on 1st January (Mha) } & \multicolumn{4}{c|}{ Decline (\% of the forest) } \\
\hline \multicolumn{1}{|c}{ Sub-region } & $\mathbf{1 9 9 0}$ & $\mathbf{1 9 9 5}$ & $\mathbf{2 0 0 0}$ & $\mathbf{2 0 0 5}$ & $\mathbf{2 0 1 0}$ & $\mathbf{2 0 1 5}$ & $\mathbf{2 0 2 0}$ & {$[\mathbf{1 9 9 0 - 2 0 2 0}$} & {$[\mathbf{1 9 9 0 - 2 0 0 0 [}$} & [2000-2010[ & [2010-2020[ \\
\hline West-Africa & 34.6 & 34.1 & 32.8 & 27.4 & 23.9 & 20.6 & 15.6 & 55.0 & 5.0 & 27.1 & 35.0 \\
\hline Central-Africa & 223.1 & 221.5 & 216.1 & 207.2 & 201.1 & 193.7 & 184.7 & 17.2 & 3.1 & 6.9 & 8.2 \\
\hline South-East Africa & 15.7 & 15.0 & 12.5 & 10.1 & 8.9 & 7.6 & 6.4 & 59.2 & 20.7 & 28.6 & 27.9 \\
\hline Central-America & 34.5 & 32.3 & 27.4 & 24.1 & 21.7 & 19.6 & 16.2 & 53.0 & 20.8 & 20.6 & 25.3 \\
\hline South-America & 670.6 & 655.4 & 628.8 & 600.9 & 583.2 & 568.9 & 548.2 & 18.2 & 6.2 & 7.3 & 6.0 \\
\hline Continental SE Asia & 73.3 & 67.2 & 57.7 & 50.2 & 44.4 & 39.9 & 34.2 & 53.3 & 21.2 & 23.2 & 22.9 \\
\hline Insular SE Asia & 237.9 & 229.5 & 207.8 & 192.9 & 180.8 & 170.5 & 159.1 & 33.1 & 12.6 & 13.0 & 12.0 \\
\hline \multicolumn{1}{|c|}{ Continent } & $\mathbf{1 9 9 0}$ & $\mathbf{1 9 9 5}$ & $\mathbf{2 0 0 0}$ & $\mathbf{2 0 0 5}$ & $\mathbf{2 0 1 0}$ & $\mathbf{2 0 1 5}$ & $\mathbf{2 0 2 0}$ & {$[\mathbf{1 9 9 0 - 2 0 2 0}[$} & {$[\mathbf{1 9 9 0 - 2 0 0 0 [}$} & {$[\mathbf{2 0 0 0 - 2 0 1 0}[$} & {$[\mathbf{2 0 1 0 - 2 0 2 0}$} \\
\hline Africa & 273.4 & 270.6 & 261.4 & 244.7 & 234.0 & 221.9 & 206.7 & 24.4 & 4.4 & 10.5 & 11.7 \\
\hline Latin-America & 705.1 & 687.7 & 656.1 & 625.0 & 604.9 & 588.5 & 564.4 & 19.9 & 6.9 & 7.8 & 6.7 \\
\hline Asia-Oceania & 311.1 & 296.7 & 265.6 & 243.2 & 225.2 & 210.4 & 193.3 & 37.9 & 14.6 & 15.2 & 14.2 \\
\hline Total & 1267.1 & $\mathbf{1 2 3 2 . 4}$ & $\mathbf{1 1 6 0 . 6}$ & $\mathbf{1 0 9 0 . 4}$ & $\mathbf{1 0 4 1 . 5}$ & $\mathbf{9 9 8 . 2}$ & $\mathbf{9 6 4 . 4}$ & $\mathbf{2 3 . 9}$ & $\mathbf{8 . 4}$ & $\mathbf{1 0 . 3}$ & $\mathbf{7 . 4}$ \\
\hline
\end{tabular}

(b)

\begin{tabular}{|c|c|c|c|c|c|c|c|c|c|c|c|}
\hline \multirow[b]{2}{*}{ Sub-region } & \multicolumn{7}{|c|}{ Area of TMF (undisturbed and degraded) at the end of the year (Mha) } & \multicolumn{4}{|c|}{ Decline (\% of the forest) } \\
\hline & 1990 & 1995 & 2000 & 2005 & 2010 & 2015 & 2020 & [1990-2020[ & {$[1990-2000[$} & {$[2000-2010[$} & [2010-2020 \\
\hline West-Africa & 34.6 & 34.3 & 33.3 & 29.8 & 27.4 & 25.1 & 22.1 & 36.0 & 3.6 & 17.8 & 19.3 \\
\hline Central-Africa & 223.1 & 222.3 & 218.6 & 212.7 & 208.9 & 204.4 & 199.9 & 10.4 & 2.0 & 4.4 & 4.3 \\
\hline South-East Africa & 15.7 & 15.2 & 12.9 & 11.0 & 10.1 & 9.2 & 8.5 & 45.9 & 17.8 & 21.8 & 15.9 \\
\hline Central-America & 34.5 & 32.8 & 29.0 & 26.8 & 25.3 & 24.0 & 22.1 & 35.9 & 16.0 & 12.8 & 12.5 \\
\hline South-America & 670.6 & 657.7 & 635.5 & 613.7 & 601.0 & 592.4 & 581.6 & 13.3 & 5.2 & 5.4 & 3.2 \\
\hline Continental SE Asia & 73.3 & 69.1 & 61.3 & 55.7 & 52.0 & 49.2 & 46.4 & 36.6 & 16.3 & 15.2 & 10.6 \\
\hline Insular SE Asia & 237.9 & 232.6 & 218.4 & 208.9 & 201.2 & 194.9 & 190.2 & 20.0 & 8.2 & 7.9 & 5.5 \\
\hline Continent & 1990 & 1995 & 2000 & 2005 & 2010 & 2015 & 2020 & [1990-2020[ & [1990-2000[ & [2000-2010[ & [2010-2020] \\
\hline Africa & 273.4 & 271.7 & 264.8 & 253.5 & 246.4 & 238.7 & 227.7 & 16.7 & 3.1 & 7.0 & 7.6 \\
\hline Latin-America & 705.1 & 690.5 & 664.5 & 640.5 & 626.3 & 616.4 & 599.2 & 15.0 & 5.8 & 5.7 & 4.3 \\
\hline Asia-Oceania & 311.1 & 301.7 & 279.7 & 264.5 & 253.2 & 244.1 & 232.8 & 25.2 & 10.1 & 9.5 & 8.1 \\
\hline Total & 1267.1 & 1241.4 & 1186.5 & 1136.0 & 1103.4 & 1076.6 & 1059.6 & 16.4 & 6.4 & 7.0 & 4.0 \\
\hline
\end{tabular}


952 Table 2. Average annual losses of undisturbed tropical moist forest areas (in million ha) between 9531990 and 2020 over intervals of 5 year, 30 year (1990-2020), 20 year (2000-2020), and 10 years 954 (1990-2000,2000-2010, 2010-2020) by sub-region and continent: (a) annual losses due to 955 deforestation and degradation, (b) annual losses due to deforestation, (c) annual losses due to degradation, (d) annual losses due to direct deforestation, (e) annual degradation before deforestation, (f) annual losses due to deforestation followed by regrowth and (g) average percentage of invalid observations over the baseline TMF domain. The values appearing in grey color indicate values derived from an average percentage of invalid observations higher than $40 \%$.

a) total annual loss due to deforestation and degradation

\begin{tabular}{|c|c|c|c|c|c|c|c|c|c|c|}
\hline \multirow[b]{2}{*}{ Sub-region } & \multicolumn{10}{|c|}{ Annual loss of Undisturbed TMF areas (Mha) } \\
\hline & {$[1990-1995[$} & [1995-2000[ & {$[2000-2005[$} & [2005-2010[ & {$[2010-2015[$} & [2015-2020[ & [1990-2020[ & {$[1990-2000[$} & {$[2000-2010[$} & [2010-2020[ \\
\hline West-Africa & 0.10 & 0.24 & 1.08 & 0.70 & 0.67 & 1.01 & 0.6 & 0.2 & 0.9 & 0.8 \\
\hline Central-Africa & 0.33 & 1.07 & 1.79 & 1.22 & 1.49 & 1.79 & 1.3 & 0.7 & 1.5 & 1.5 \\
\hline South-East Africa & 0.13 & 0.52 & 0.47 & 0.24 & 0.26 & 0.24 & 0.3 & 0.3 & 0.4 & 0.3 \\
\hline Central-America & 0.45 & 0.99 & 0.66 & 0.47 & 0.43 & 0.67 & 0.6 & 0.7 & 0.6 & 0.6 \\
\hline South-America & 3.03 & 5.33 & 5.56 & 3.56 & 2.85 & 4.14 & 4.1 & 4.2 & 4.6 & 4.1 \\
\hline Continental SE Asia & 1.21 & 1.90 & 1.50 & 1.17 & 0.89 & 1.14 & 1.3 & 1.6 & 1.3 & 1.2 \\
\hline Insular SE Asia & 1.68 & 4.32 & 2.98 & 2.43 & 2.07 & 2.28 & 2.6 & 3.0 & 2.7 & 2.5 \\
\hline Continent & [1990-1995[ & [1995-2000[ & [2000-2005 & [2005-2010] & [2010-2015[ & [2015-2020[ & [1990-2020[ & [1990-2000[ & [2000-2010[ & [2010-2020] \\
\hline Africa & 0.56 & 1.82 & 3.34 & 2.15 & 2.42 & 3.04 & 2.2 & 1.2 & 2.7 & 2.6 \\
\hline Latin-America & 3.48 & 6.32 & 6.22 & 4.03 & 3.27 & 4.81 & 4.7 & 4.9 & 5.1 & 4.8 \\
\hline Asia-Oceania & 2.89 & 6.22 & 4.48 & 3.60 & 2.96 & 3.42 & 3.9 & 4.6 & 4.0 & 3.7 \\
\hline Total & 6.93 & 14.37 & 14.04 & 9.78 & 8.66 & 11.27 & 10.8 & 10.6 & 11.9 & 11.1 \\
\hline
\end{tabular}

b) annual loss due to deforestation (with or without prior degradation)

\begin{tabular}{|c|c|c|c|c|c|c|c|c|c|c|}
\hline \multirow[b]{2}{*}{ Sub-region } & \multicolumn{10}{|c|}{ Total deforestation on an annual basis by period (Mha) } \\
\hline & {$[1990-1995[$} & [1995-2000[ & [2000-2005[ & [2005-2010[ & [2010-2015[ & [2015-2020[ & [1990-2020[ & {$[1990-2000[$} & {$[2000-2010[$} & [2010-2020[ \\
\hline West-Africa & 0.06 & 0.19 & 0.71 & 0.48 & 0.45 & 0.60 & 0.4 & 0.1 & 0.6 & 0.5 \\
\hline Central-Africa & 0.17 & 0.74 & 1.18 & 0.76 & 0.90 & 0.91 & 0.8 & 0.5 & 1.0 & 0.9 \\
\hline South-East Africa & 0.10 & 0.45 & 0.38 & 0.18 & 0.18 & 0.14 & 0.2 & 0.3 & 0.3 & 0.2 \\
\hline Central-America & 0.34 & 0.76 & 0.45 & 0.29 & 0.26 & 0.37 & 0.4 & 0.6 & 0.4 & 0.3 \\
\hline South-America & 2.57 & 4.44 & 4.35 & 2.54 & 1.73 & 2.16 & 3.0 & 3.5 & 3.4 & 1.9 \\
\hline Continental SE Asia & 0.84 & 1.55 & 1.13 & 0.74 & 0.56 & 0.54 & 0.9 & 1.2 & 0.9 & 0.6 \\
\hline Insular SE Asia & 1.05 & 2.83 & 1.91 & 1.53 & 1.27 & 0.94 & 1.6 & 1.9 & 1.7 & 1.1 \\
\hline Continent & [1990-1995[ & [1995-2000[ & [2000-2005[ & [2005-2010[ & [2010-2015[ & [2015-2020[ & [1990-2020[ & [1990-2000[ & [2000-2010[ & [2010-2020[ \\
\hline Africa & 0.33 & 1.38 & 2.26 & 1.42 & 1.54 & 1.65 & 1.43 & 0.86 & 1.84 & 1.59 \\
\hline Latin-America & 2.91 & 5.21 & 4.80 & 2.83 & 1.99 & 2.53 & 3.38 & 4.06 & 3.82 & 2.26 \\
\hline Asia-Oceania & 1.89 & 4.38 & 3.04 & 2.27 & 1.83 & 1.48 & 2.48 & 3.14 & 2.65 & 1.65 \\
\hline Total & 5.14 & 10.97 & 10.10 & 6.52 & 5.35 & 5.66 & 7.29 & 8.06 & 8.31 & 5.51 \\
\hline
\end{tabular}


c) annual loss due to degradation (followed or not by deforestation)

Total degradation on an annual basis by period (Mha)

\begin{tabular}{|c|c|c|c|c|c|c|c|c|c|c|}
\hline & \multicolumn{10}{|c|}{ Total degradation on an annual basis by period (Mha) } \\
\hline Sub-region & [1990-1995[ & {$[1995-2000[$} & {$[2000-2005[$} & [2005-2010[ & [2010-2015[ & [2015-2020[ & [1990-2020[ & [1990-2000[ & [2000-2010[ ] & [2010-2020[ \\
\hline West-Africa & 0.08 & 0.16 & 0.87 & 0.50 & 0.35 & 0.61 & 0.4 & 0.1 & 0.7 & 0.5 \\
\hline Central-Africa & 0.28 & 0.83 & 1.40 & 0.91 & 0.92 & 1.24 & 0.9 & 0.6 & 1.2 & 1.1 \\
\hline South-East Africa & 0.09 & 0.27 & 0.28 & 0.14 & 0.13 & 0.13 & 0.2 & 0.2 & 0.2 & 0.1 \\
\hline Central-America & 0.29 & 0.64 & 0.49 & 0.34 & 0.27 & 0.45 & 0.4 & 0.5 & 0.4 & 0.4 \\
\hline South-America & 1.25 & 2.29 & 2.61 & 1.83 & 1.59 & 2.54 & 2.0 & 1.8 & 2.2 & 2.1 \\
\hline Continental SE Asia & 0.88 & 1.23 & 1.03 & 0.81 & 0.49 & 0.78 & 0.9 & 1.1 & 0.9 & 0.6 \\
\hline Insular SE Asia & 1.16 & 2.80 & 1.98 & 1.39 & 1.03 & 1.65 & 1.7 & 2.0 & 1.7 & 1.3 \\
\hline Continent & [1990-1995[ & [1995-2000[ & [2000-2005[ & [2005-2010[ & [2010-2015[ & [2015-2020[ & [1990-2020[ & [1990-2000[] & [2000-2010[] & [2010-2020] \\
\hline Africa & 0.45 & 1.26 & 2.56 & 1.55 & 1.40 & 1.98 & 1.53 & 0.86 & 2.05 & 1.69 \\
\hline Latin-America & 1.54 & 2.93 & 3.10 & 2.16 & 1.85 & 2.99 & 2.43 & 2.24 & 2.63 & 2.42 \\
\hline Asia-Oceania & 2.04 & 4.03 & 3.00 & 2.21 & 1.51 & 2.43 & 2.54 & 3.04 & 2.61 & 1.97 \\
\hline Total & 4.03 & 8.23 & 8.66 & 5.92 & 4.77 & 7.40 & 6.50 & 6.13 & 7.29 & 6.09 \\
\hline
\end{tabular}

d) annual loss due to direct deforestation (without prior degradation)

\begin{tabular}{|c|c|c|c|c|c|c|c|c|c|c|}
\hline & \multicolumn{10}{|c|}{ Annual direct deforestation by period (Mha) } \\
\hline Sub-region & [1990-1995[ & [1995-2000[ & [2000-2005[ & [2005-2010[ & [2010-2015[ & [2015-2020[ & [1990-2020[] & [1990-2000[ & [2000-2010[ & [2010-2020[ \\
\hline West-Africa & 0.02 & 0.08 & 0.21 & 0.19 & 0.32 & 0.40 & 0.2 & 0.0 & 0.2 & 0.4 \\
\hline Central-Africa & 0.05 & 0.24 & 0.38 & 0.31 & 0.57 & 0.56 & 0.4 & 0.1 & 0.3 & 0.6 \\
\hline South-East Africa & 0.05 & 0.24 & 0.19 & 0.10 & 0.13 & 0.10 & 0.1 & 0.1 & 0.1 & 0.1 \\
\hline Central-America & 0.16 & 0.34 & 0.17 & 0.13 & 0.16 & 0.22 & 0.2 & 0.2 & 0.2 & 0.2 \\
\hline South-America & 1.78 & 3.05 & 2.95 & 1.73 & 1.26 & 1.61 & 2.1 & 2.4 & 2.3 & 1.4 \\
\hline Continental SE Asia & 0.33 & 0.66 & 0.48 & 0.36 & 0.41 & 0.36 & 0.4 & 0.5 & 0.4 & 0.4 \\
\hline Insular SE Asia & 0.52 & 1.53 & 1.00 & 1.03 & 1.04 & 0.62 & 1.0 & 1.0 & 1.0 & 0.8 \\
\hline Continent & [1990-1995[ & [1995-2000[ & {$[2000-2005[$} & {$[2005-2010[$} & {$[2010-2015[$} & [2015-2020[ & {$[1990-2020[$} & [1990-2000[ & [2000-2010[ & [2010-2020[ \\
\hline Africa & 0.11 & 0.56 & 0.78 & 0.60 & 1.02 & 1.06 & 0.69 & 0.34 & 0.69 & 1.04 \\
\hline Latin-America & 1.94 & 3.39 & 3.12 & 1.86 & 1.42 & 1.82 & 2.26 & 2.66 & 2.49 & 1.62 \\
\hline Asia-Oceania & 0.85 & 2.19 & 1.48 & 1.39 & 1.45 & 0.99 & 1.39 & 1.52 & 1.44 & 1.22 \\
\hline Total & 2.90 & 6.14 & 5.38 & 3.86 & 3.89 & 3.87 & 4.34 & 4.52 & 4.62 & 3.88 \\
\hline
\end{tabular}

e) annual degradation before deforestation

\begin{tabular}{|c|c|c|c|c|c|c|c|c|c|c|}
\hline \multirow[b]{2}{*}{ Sub-region } & \multicolumn{10}{|c|}{ Annual degradation before deforestation by period (Mha) } \\
\hline & [1990-1995[ & [1995-2000[ & {$[2000-2005[$} & {$[2005-2010[$} & {$[2010-2015[$} & [2015-2020[] & [1990-2020[] & [1990-2000[ & [2000-2010[ & [2010-2020[ \\
\hline West-Africa & 0.04 & 0.11 & 0.50 & 0.28 & 0.14 & 0.20 & 0.2 & 0.1 & 0.4 & 0.2 \\
\hline Central-Africa & 0.12 & 0.50 & 0.79 & 0.45 & 0.33 & 0.35 & 0.4 & 0.3 & 0.6 & 0.3 \\
\hline South-East Africa & 0.06 & 0.21 & 0.19 & 0.08 & 0.05 & 0.04 & 0.1 & 0.1 & 0.1 & 0.0 \\
\hline Central-America & 0.18 & 0.42 & 0.28 & 0.16 & 0.10 & 0.16 & 0.2 & 0.3 & 0.2 & 0.1 \\
\hline South-America & 0.79 & 1.40 & 1.40 & 0.81 & 0.47 & 0.55 & 0.9 & 1.1 & 1.1 & 0.5 \\
\hline Continental SE Asia & 0.51 & 0.89 & 0.65 & 0.38 & 0.15 & 0.18 & 0.5 & 0.7 & 0.5 & 0.2 \\
\hline Insular SE Asia & 0.53 & 1.31 & 0.91 & 0.50 & 0.23 & 0.31 & 0.6 & 0.9 & 0.7 & 0.3 \\
\hline Continent & [1990-1995[ & [1995-2000[ & {$[2000-2005[$} & [2005-2010[ & [2010-2015[ & [2015-2020[ & [1990-2020[ & [1990-2000[ & [2000-2010[ & [2010-2020[ \\
\hline Africa & 0.22 & 0.82 & 1.48 & 0.82 & 0.52 & 0.59 & 0.74 & 0.52 & 1.15 & 0.55 \\
\hline Latin-America & 0.98 & 1.82 & 1.68 & 0.97 & 0.57 & 0.71 & 1.12 & 1.40 & 1.33 & 0.64 \\
\hline Asia-Oceania & 1.05 & 2.19 & 1.56 & 0.88 & 0.38 & 0.49 & 1.09 & 1.62 & 1.22 & 0.44 \\
\hline Total & 2.24 & 4.83 & 4.72 & 2.66 & 1.47 & 1.79 & 2.95 & 3.54 & 3.69 & 1.63 \\
\hline
\end{tabular}


f) annual deforestation followed by a regrowth

\begin{tabular}{|c|c|c|c|c|c|c|c|c|c|c|}
\hline & \multicolumn{10}{|c|}{ Total deforestation followed by regrowth on an annual basis by period (Mha) } \\
\hline Sub-region & [1990-1995[ & [1995-2000[ & {$[2000-2005[$} & [2005-2010[ $]$ & [2010-2015[ & [2015-2020[ & [1990-2020[ & [1990-2000[ & [2000-2010[ & [2010-2020[ \\
\hline West-Africa & 0.00 & 0.00 & 0.01 & 0.04 & 0.06 & 0.03 & 0.0 & 0.0 & 0.0 & 0.0 \\
\hline Central-Africa & 0.02 & 0.04 & 0.07 & 0.10 & 0.13 & 0.06 & 0.1 & 0.0 & 0.1 & 0.1 \\
\hline South-East Africa & 0.00 & 0.01 & 0.02 & 0.03 & 0.03 & 0.01 & 0.0 & 0.0 & 0.0 & 0.0 \\
\hline Central-America & 0.05 & 0.09 & 0.07 & 0.07 & 0.05 & 0.02 & 0.1 & 0.1 & 0.1 & 0.0 \\
\hline South-America & 0.21 & 0.40 & 0.50 & 0.49 & 0.37 & 0.20 & 0.4 & 0.3 & 0.5 & 0.3 \\
\hline Continental SE Asia & 0.10 & 0.20 & 0.24 & 0.23 & 0.14 & 0.06 & 0.2 & 0.2 & 0.2 & 0.1 \\
\hline Insular SE Asia & 0.11 & 0.33 & 0.44 & 0.42 & 0.30 & 0.15 & 0.3 & 0.2 & 0.4 & 0.2 \\
\hline Continent & [1990-1995[ & [1995-2000[ & [2000-2005[ & [2005-2010[ & [2010-2015[ & [2015-2020[ & [1990-2020[ & [1990-2000] & [2000-2010] & [2010-2020] \\
\hline Africa & 0.02 & 0.06 & 0.10 & 0.17 & 0.21 & 0.10 & 0.11 & 0.04 & 0.13 & 0.15 \\
\hline Latin-America & 0.26 & 0.48 & 0.58 & 0.56 & 0.43 & 0.22 & 0.42 & 0.37 & 0.57 & 0.32 \\
\hline Asia-Oceania & 0.21 & 0.53 & 0.68 & 0.65 & 0.44 & 0.21 & 0.45 & 0.37 & 0.66 & 0.32 \\
\hline Total & 0.50 & 1.06 & 1.36 & 1.37 & 1.08 & 0.53 & 0.98 & 0.78 & 1.37 & 0.80 \\
\hline
\end{tabular}

g) average percentage of invalid observations over the TMF domain per period and per year

\begin{tabular}{|c|c|c|c|c|c|c|c|}
\hline \multirow[b]{2}{*}{ Sub-region } & \multicolumn{7}{|c|}{ Average \% of Invalid observations (over the total forest domain, per period) } \\
\hline & [1982-1990[ & [1990-1995[ & [1995-2000[ & [2000-2005[ & [2005-2010[ & [2010-2015[ & [2015-2020[ \\
\hline West-Africa & 98.1 & 87.1 & 82.5 & 40.0 & 2.8 & 0.4 & 0.0 \\
\hline Central-Africa & 99.4 & 94.7 & 80.8 & 37.2 & 6.7 & 2.9 & 0.4 \\
\hline South-East Africa & 97.9 & 80.8 & 20.7 & 3.9 & 1.3 & 0.8 & 0.1 \\
\hline Central-America & 50.1 & 12.4 & 4.3 & 1.2 & 0.4 & 0.1 & 0.0 \\
\hline South-America & 30.5 & 1.2 & 0.6 & 0.2 & 0.0 & 0.0 & 0.0 \\
\hline Continental SE Asia & 54.5 & 14.6 & 1.3 & 0.4 & 0.0 & 0.0 & 0.0 \\
\hline Insular SE Asia & 34.3 & 16.3 & 4.2 & 0.8 & 0.1 & 0.1 & 0.0 \\
\hline Continent & [1982-1990[ & [1990-1995[ & [1995-2000[ & [2000-2005[ & [2005-2010[ & [2010-2015[ & [2015-2020[ \\
\hline Africa & 99.1 & 92.9 & 77.6 & 35.7 & 5.9 & 2.4 & 0.3 \\
\hline Latin-America & 31.3 & 1.6 & 0.8 & 0.2 & 0.1 & 0.0 & 0.0 \\
\hline Asia-Oceania & 29.5 & 12.0 & 3.7 & 1.3 & 0.3 & 0.2 & 0.0 \\
\hline Total & 21.2 & 31.9 & 23.1 & 10.1 & 2.3 & 0.8 & 0.1 \\
\hline
\end{tabular}

\section{Average \% of Invalid observations (over the total forest domain, per year)}

\begin{tabular}{|l|c|c|c|c|c|c|c|c|}
\hline \multicolumn{1}{|c|}{ Sub-region } & $\mathbf{1 9 8 2}$ & $\mathbf{1 9 9 0}$ & $\mathbf{1 9 9 5}$ & $\mathbf{2 0 0 0}$ & $\mathbf{2 0 0 5}$ & $\mathbf{2 0 1 0}$ & $\mathbf{2 0 1 5}$ & $\mathbf{2 0 1 9}$ \\
\hline West-Africa & 100.0 & 90.8 & 84.3 & 71.8 & 5.9 & 0.7 & 0.2 & 0.0 \\
\hline Central-Africa & 100.0 & 97.7 & 87.6 & 67.8 & 10.2 & 3.7 & 1.9 & 0.0 \\
\hline South-East Africa & 100.0 & 92.1 & 41.5 & 8.4 & 1.5 & 1.0 & 0.5 & 0.0 \\
\hline Central-America & 69.4 & 17.0 & 5.8 & 1.8 & 0.7 & 0.2 & 0.0 & 0.0 \\
\hline South-America & 55.6 & 1.7 & 0.8 & 0.3 & 0.1 & 0.0 & 0.0 & 0.0 \\
\hline Continental SE Asia & 55.2 & 49.1 & 2.0 & 1.0 & 0.0 & 0.0 & 0.0 & 0.0 \\
\hline Insular SE Asia & 34.6 & 31.2 & 6.5 & 1.9 & 0.2 & 0.1 & 0.0 & 0.0 \\
\hline \multicolumn{1}{|c|}{ Continent } & $\mathbf{1 9 8 2}$ & $\mathbf{1 9 9 0}$ & $\mathbf{1 9 9 5}$ & $\mathbf{2 0 0 0}$ & $\mathbf{2 0 0 5}$ & $\mathbf{2 0 1 0}$ & $\mathbf{2 0 1 5}$ & $\mathbf{2 0 1 9}$ \\
\hline Africa & 100.0 & 93.5 & 71.2 & 49.3 & 5.9 & 1.8 & 0.9 & 0.0 \\
\hline Latin-America & 62.5 & 9.4 & 3.3 & 1.0 & 0.4 & 0.1 & 0.0 & 0.0 \\
\hline Asia-Oceania & 44.9 & 40.2 & 4.3 & 1.4 & 0.1 & 0.1 & 0.0 & 0.0 \\
\hline Total & 69.1 & 47.7 & $\mathbf{2 6 . 2}$ & $\mathbf{1 7 . 3}$ & $\mathbf{2 . 1}$ & $\mathbf{0 . 7}$ & $\mathbf{0 . 3}$ & $\mathbf{0 . 0}$ \\
\hline
\end{tabular}


980 Table 3. Total areas and proportions of tropical moist forest disturbances (deforestation without

981 regrowth, regrowth after deforestation, forest degradation) and reforestation areas (initially other

982 land cover) over the period 1990-2020 for each sub-region and continent (areas in million ha and 983 proportions in percentage).

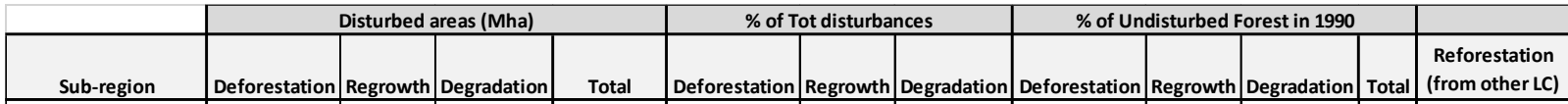

\begin{tabular}{|c|c|c|c|c|c|c|c|c|c|c|c|c|}
\hline West-Africa & 11.8 & 0.7 & 6.5 & 19.0 & 61.9 & 3.7 & 34.5 & 34.0 & 2.0 & 18.9 & 55.0 & 0.4 \\
\hline Central-Africa & 21.2 & 2.1 & 15.1 & 38.4 & 55.2 & 5.4 & 39.4 & 9.5 & 0.9 & 6.8 & 17.2 & 1.1 \\
\hline South-East Africa & 6.7 & 0.5 & 2.1 & 9.3 & 71.9 & 5.7 & 22.4 & 42.5 & 3.4 & 13.3 & 59.2 & 0.2 \\
\hline Central-America & 10.6 & 1.8 & 5.9 & 18.3 & 58.0 & 9.7 & 32.3 & 30.7 & 5.1 & 17.1 & 53.0 & 0.7 \\
\hline South-America & 78.1 & 10.9 & 33.4 & 122.4 & 63.8 & 8.9 & 27.3 & 11.6 & 1.6 & 5.0 & 18.2 & 4.0 \\
\hline Continental SE Asia & 22.0 & 4.9 & 12.2 & 39.1 & 56.2 & 12.4 & 31.4 & 30.0 & 6.6 & 16.7 & 53.3 & 2.0 \\
\hline Insular SE Asia & 38.9 & 8.7 & 31.1 & 78.8 & 49.4 & 11.1 & 39.5 & 16.4 & 3.7 & 13.1 & 33.1 & 1.6 \\
\hline Continent & Deforestation & Regrowth & Degradation & Total & Deforestation & Regrowth & Degradation & Deforestation & Regrowth & Degradation & Total & $\begin{array}{c}\text { Reforestation } \\
\text { (from other LC) }\end{array}$ \\
\hline Africa & 39.6 & 3.3 & 23.8 & 66.7 & 59.4 & 4.9 & 35.6 & 14.5 & 1.2 & 8.7 & 24.4 & 1.6 \\
\hline Latin-America & 88.7 & 12.6 & 39.3 & 140.7 & 63.1 & 9.0 & 27.9 & 12.6 & 1.8 & 5.6 & 19.9 & 4.7 \\
\hline Asia-Oceania & 60.9 & 13.6 & 43.4 & 117.8 & 51.7 & 11.5 & 36.8 & 19.6 & 4.4 & 13.9 & 37.9 & 3.6 \\
\hline Total & 189.2 & 29.5 & 106.5 & 325.2 & 58.2 & 9.1 & 32.7 & 14.9 & 2.3 & 8.4 & 25.7 & 10.0 \\
\hline
\end{tabular}


1000 Table 4. Comparison of estimates of annual deforested areas (in million ha / year) from previous 1001 studies and our study, over the tropical belt, over the three continents and Brazil.

\begin{tabular}{|c|c|c|c|c|c|c|c|c|c|}
\hline \multirow{2}{*}{\multicolumn{2}{|c|}{ Forest extent }} & \multicolumn{2}{|c|}{ Hansen et al. 2013} & \multirow{2}{*}{ 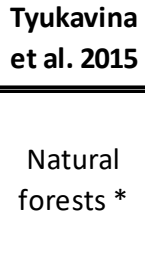 } & \multirow{2}{*}{\begin{tabular}{|c|}
$\begin{array}{c}\text { Keenan et al. } \\
\mathbf{2 0 1 5}\end{array}$ \\
All tropical \\
forests \\
(evergreen \& \\
deciduous)
\end{tabular}} & \multirow{2}{*}{$\begin{array}{l}\text { PRODES- } \\
\text { INPE } \\
\\
\text { Primary } \\
\text { forest }\end{array}$} & \multicolumn{3}{|c|}{ This Study } \\
\hline & & $\begin{array}{l}\text { Whole TMF } \\
\text { (undisturbed }\end{array}$ & $\begin{array}{l}\text { Primary } \\
\text { forest }\end{array}$ & & & & $\begin{array}{c}\text { Tropical } \\
\text { moist }\end{array}$ & $\begin{array}{l}\text { TMF } \\
\text { excluding }\end{array}$ & $\begin{array}{l}\text { Primary } \\
\text { forest }\end{array}$ \\
\hline \multirow{5}{*}{$\begin{array}{l}\text { Pan-tropical } \\
\text { region }\end{array}$} & 2001-2010 & 4.67 & & & 7.24 & & 7.72 & & \\
\hline & 2001-2012 & 4.80 & & $6.5 \pm 0.7$ & & & 7.19 & 6.44 & \\
\hline & 2001-2015 & 5.07 & & & 6.66 & & 6.95 & & \\
\hline & 2010-2019 & 6.87 & & & & & 5.51 & & \\
\hline & 2001-2019 & 5.79 & & & & & 6.66 & & \\
\hline \multirow{2}{*}{ Africa } & 2001-2012 & 0.73 & & $1.21 \pm 0.4$ & & & 1.60 & 1.57 & \\
\hline & 2001-2019 & 1.28 & & & & & 1.64 & & \\
\hline \multirow{2}{*}{ Latin America } & 2001-2012 & 2.19 & & $3.7 \pm 0.5$ & & & 3.25 & 3.19 & \\
\hline & 2001-2019 & 2.41 & & & & & 2.93 & & \\
\hline \multirow{2}{*}{ Asia-Oceania } & 2001-2012 & 1.89 & & $1.6 \pm 0.4$ & & & 2.34 & 1.67 & \\
\hline & 2001-2019 & 2.10 & & & & & 2.09 & & \\
\hline \multirow{4}{*}{ Brazil } & 2001-2010 & 1.61 & 1.35 & & & 1.65 & 2.55 & & 1.57 \\
\hline & 2001-2012 & 1.54 & 1.26 & $2.1 \pm 0.3$ & & 1.47 & 2.32 & 2.27 & 1.42 \\
\hline & 2010-2019 & 1.64 & 1.34 & & & 0.67 & 1.63 & & 1.04 \\
\hline & 2001-2019 & 1.64 & 1.35 & & & 1.19 & 2.10 & & 1.31 \\
\hline
\end{tabular}

